\title{
Palynofloras and vertebrates from Muğla-Ören region (SW Turkey) and palaeoclimate of the Middle Burdigalian-Langhian period in Turkey
}

\author{
Mine Sezgül Kayseri ÖZer, Funda Akgün, Serdar Mayda \& TANJu KayA
}

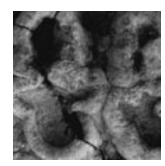

\begin{abstract}
The Miocene is the last warm episode in Earth history, and this episode was well recorded in Turkey as shown by plant distribution and inferred numerical temperature values. In this study, Ören-Kultak, Hüssamlar and Karacaağaç palynofloras from western Turkey, which are characterized by the thermophilous plants (Engelhardia, Sapotaceae, Cyrillaceae, Avicennia, Arecaceae, Palmae), are described. Age determinations of these palynofloras (middle Burdigalian-Langhian) are strengthened by the mammalian fossil record (MN4-5) and strontium isotope results. Palaeoclimate is humid and warm subtropical during the middle Burdigalian-Langhian time interval in Europe and Turkey. However, temperature difference has been observed between Europe and Turkey during this time interval and it could be explained by the palaeogeographic position of countries. Despite some discrepancies in the climatic values and palaeovegetation groups, warm climatic conditions are recorded, based on the palynofloras, in Turkey (Çayırhan, Havza, Çan, Etili, Gönen, Bigadiç, Emet, Kirka and Kestelek, Sabuncubeli, Soma, Tire, Kuloğulları, Başçayır, Hüssamlar and Karacaağaç), Greece and elsewhere in Europe throughout the middle Burdigalian-Langhian period. This warming is related to the Middle Miocene Climatic Optimum period. Carbon and oxygen isotope values obtained from tooth enamel of Gomphotherium sp. from Kultak and Hüssamlar indicate similar ecological condition during the Burdigalian-Langhian time. This isotopic result and high $\mathrm{MAP}_{\mathrm{DRY}}$ value from the Kultak locality are in agreement with ecological interpretation of mammalian fossils. Besides, according to the precipitation values, central and northwestern Anatolian sites provide more rainfall during the Burdigalian-Langhian time interval than the western Anatolian sites. • Key words: palynology, palaeoclimate, palaeovegetation, mammalian fossils, western Anatolia, Miocene.
\end{abstract}

KAYSERI ÖZER, M.S., AKGÜN, F., MAYDA, S. \& KAYA, T. 2014. Palynofloras and vertebrates from Muğla-Ören region (SW Turkey) and palaeoclimate of the Middle Burdigalian-Langhian period in Turkey. Bulletin of Geosciences 89(1), 137-162 (13 figures, 5 tables). Czech Geological Survey, Prague. ISSN 1214-1119. Manuscript received January 25, 2013; accepted in revised form August 6, 2013; published online January 6, 2014; issued January 21, 2014.

Mine Sezgül Kayser Özer (corresponding author) \& Funda Akgün, Department of Geological Engineering, Dokuz Eylül University, Tinaztepe Campus, Buca-İmir,TR-35160,Turkey; sezgul.kayseri@ogr.deu.edu.tr•Serdar Mayda \& Tanju Kaya, Department of Biology, Aegean University, Bornova-İzmir, Turkey

Numerous coal bearing deposits in Turkey from the Burdigalian-Langhian time interval display clear palaeoenvironmental changes and in particular the record of the Middle Miocene Climatic Optimum (e.g. Akgün 1993; Gemici et al. 1991; Akgün \& Akyol 1999; Akgün et al. 2000, 2002, 2004, 2007; Ediger 1990; Rögl 1998; Karayiğit et al. 1999; Zachos et al. 2001; Akgün \& Kayseri 2004; Popov et al. 2004; Mosburgger et al. 2005; Kayseri et al. 2006; Kayseri \& Akgün 2008; Fauqette et al. 2007; Yavuz-Iș1k 2007; Ivanov et al. 2011; Utescher et al. 2011; Kern et al. 2011). Sediments of the Milas-Ören Basin are known as potentially favorable to provide a well-controlled regional stratigraphy and lithostratigraphic correlation with the neighbour basins based on a few palaeontological studies (i.e. Nebert, unpublished report; Nakoman 1978, Kaya et al. 2001). In the Milas-Ören Basin, the Burdigalian is represented by marine sediments in the Akbük region according to the previous studies (i.e. Görür et al. 1994, 1995). Besides, Kaya et al. (2001) reported on the late Langhian (MN5-6 boundary) mammalian fossils. However, fossil evidence from terrestrial and marine sediments in the Milas-Ören Basin is not adequately studied and also the biostratigraphy of this region is not yet well-established (Fig. 1).

Sedimentary rocks at the Kultak locality are characterized by clastic sediments, which are deposited in the delta environment (Görür et al. 1994, 1995; Kayseri 2010). Terrestrial sediments at the Karacaağaç and Hüssamlar localities are represented by coal and marl alternations, and they yielded mammalian fossils. In addition, strontium analyses on mammalian teeth are used to support the age determination. Palaeoenvironmental data on these deposits were obtained from palynofloras of the Kultak, Karacaağaç and 


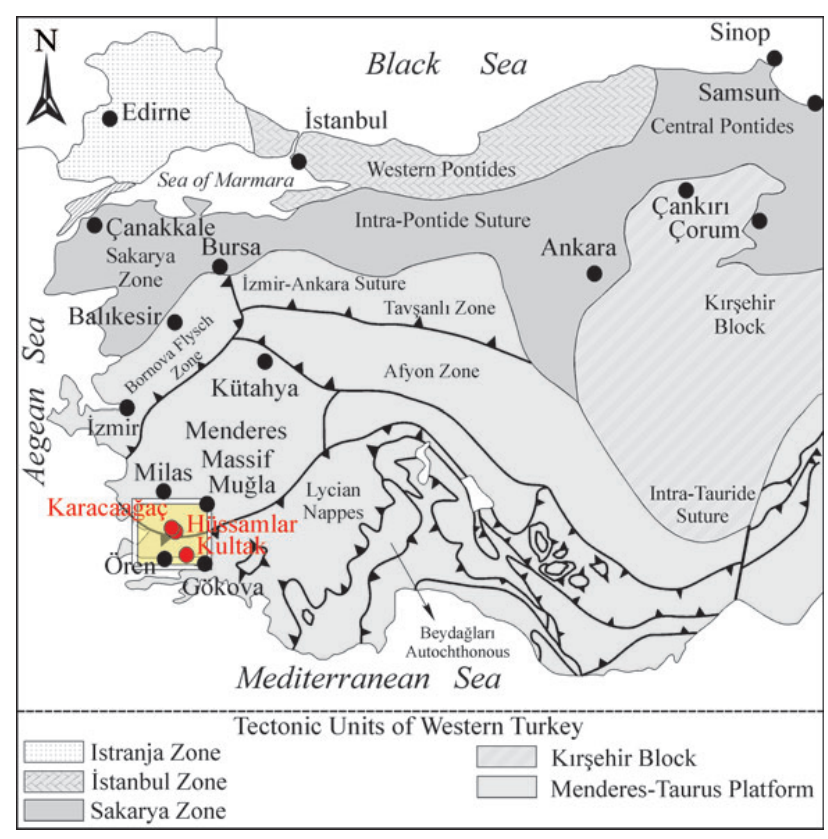

Figure 1. Main tectonic units of Turkey (after Görür \& Tüysüz 2001) and the study areas.

Hüssamlar localities, and oxygen, carbon isotopes analyses applied on mammalian fossil teeth.

Vegetation and climate history of Turkey during the Burdigalian-Langhian time interval is revealed, in addition to the present study on the Ören-Kultak, Karacaağaç, Hüssamlar localities, by the previous studies on the palynofloras from Ankara-Beypazarı correlated to "latest Burdigalian" (Güngör 1991, Whateley \& Tuncalı 1995), from Çanakkale-Çan and Balıkesir-Gönen correlated to "latest
Burdigalian-?Serravallian" (Ediger 1990), from AydınBașçayır and Kuloğulları correlated to "Langhian" (Akgün \& Akyol 1999), from İzmir-Sabuncubeli correlated to "latest Burdigalian". In addition, palynofloras studies from Spanokhorion and Evia in Greece correlated to "latest Burdigalian" and from Kolivata in Greece correlated to "Langhian" (Benda et al. 1982) provided interesting results that can be compared to those from Turkey. Taking into consideration the palaeogeography of the Burdigalian and Langhian, palaeoclimatic records from Serbia, Ukraine, Germany, Austria and Bulgaria are compared with palaeoclimatic results from Turkey and Greece.

\section{Geological setting}

Mesozoic sediments of the Lycian Nappes cover a large area between the Menderes Massif to the north and the Bey Dağları autochthonous unit to the east. These formations form the basement of the Early-Middle Miocene deposits in the Gökova region (Görür et al. 1994, Yılmaz et al. 2000, Sözbilir et al. 2005; Fig. 1). The north-south trending Ören Basin, where crop out the Oligo-Miocene sedimentary deposits, is located to the north of the Gökova gulf (Y1lmaz \& Polat 1998, Querol et al. 1999, Y1lmaz et al. 2000, Gürer \& Y1lmaz 2002). The sedimentary infill of the Ören Basin is represented by coal-bearing continental and shallow marine sediments (Gürer \& Y1lmaz 2002), in some places including reefal limestones.

The basement rocks Lycian Nappes are unconformably overlain by marine and terrestrial sediments, which are deposited during the Oligocene-Early Miocene in the Ören
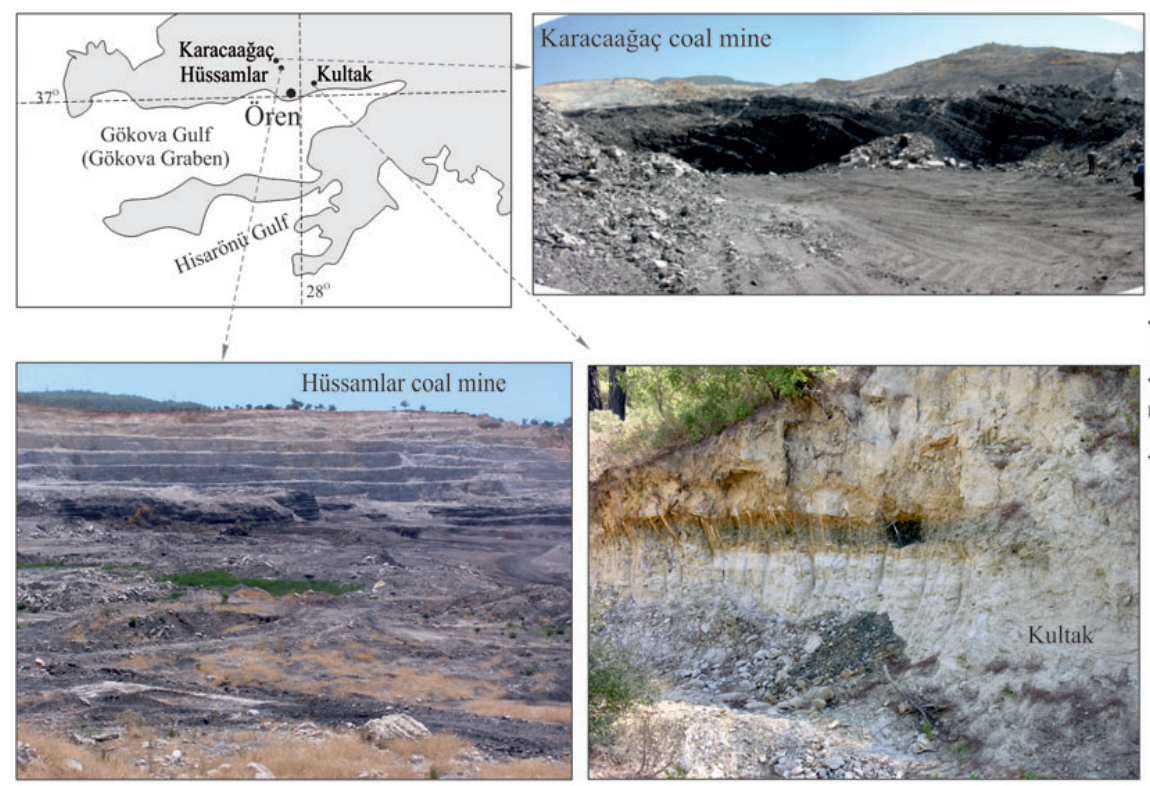

.

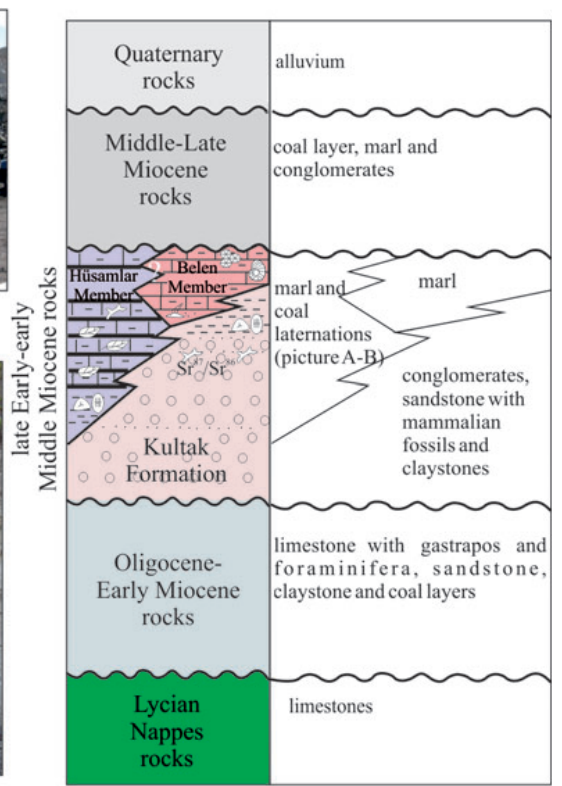

Figure 2. Generalized stratigraphic columnar section between the Kultak and Karacaağaç localities. 
region. The Kultak Formation unconformably overlies the basement and this formation laterally and vertically passes to the Hüssamlar and Belen members. The Kultak Formation is deposited during the late Early-early Middle Miocene interval based on palynological records, the mammalian fossil and strontium isotopic results. The Belen Member is characterized by marine sediments with foraminifers, gastropods, bivalves and corals in the Kultak area (Kayseri 2010, Kayseri \& Akgün 2010). The Hüssamlar Member is represented by marls with leaf fossils and coal alternations in the Hüssamlar and Karacaağaç areas (Fig. 2). Quaternary alluvial sediments cover on all the older units in the study area. The palynological data are obtained from the claystones of the upper part of the Kultak Formation (in the Kultak area) and claystones and coals of the Hüssamlar Member (in Hüssamlar and Karacaağaç areas). Mammalian fossils are collected from the clastic rocks in the Kultak Formation and coal bearing sediments in the Hüssamlar Member (Kaya et al. 2001, Kayseri 2010; Fig. 2).

\section{Material and methods}

This study is based on sporomorphs extracted from the measured stratigraphic sections of the Kultak, Karacaağaç and Hüssamlar localities. All samples were processed at the Dokuz Eylül University in İzmir using standard palynological preparation techniques, including treatment with $\mathrm{HCl}, \mathrm{HF}$ and $\mathrm{HNO}_{3}$. Separation of the spores and pollen from the rest of the residue was carried out using $\mathrm{ZnCl}_{2}\left(2.0 \mathrm{~g}\right.$ per $\left.\mathrm{cm}^{3}\right)$. Forty-seven samples from the terrestrial sediments in the Hüssamlar, Karacaağaç and Kultak localities were found suitable for quantitative pollen analysis. Palynoflora description was carried out in the Senckenberg Museum in Frankfurt and Dokuz Eylül University. Changes of the palynomorph abundance are handled by the TILIA (2.0.2.) program. Besides, mammalian fossils are determined in the Aegean University.

The use of multivariate analytical methods in paleontological studies has become more widespread in the last twenty years (Kovach 1988, 1989). The choice of methods depends on the type of data and on the specific problems being solved (Kovach 1989). To interpret the faunal similarities, the statistical analyses were performed with the Paleontological Statistics Software (PAST), using the UPGMA (unweighted pair group method with arithmetic mean) cluster algorithm method and the Jaccard's similarity index (Hammer et al. 2001). Additionally, in this study, the isotopic results of oxygen and carbon are obtained from the first lower molar of Gomphotherium sp. Thus, the isotopic analyses results were combined with temperature and precipitation results evidenced by floral analyses to support the palaeovegetational investigations.

The coexistence approach (CA) method, which is developed by Mosbrugger \& Utescher (1997), is used to obtain

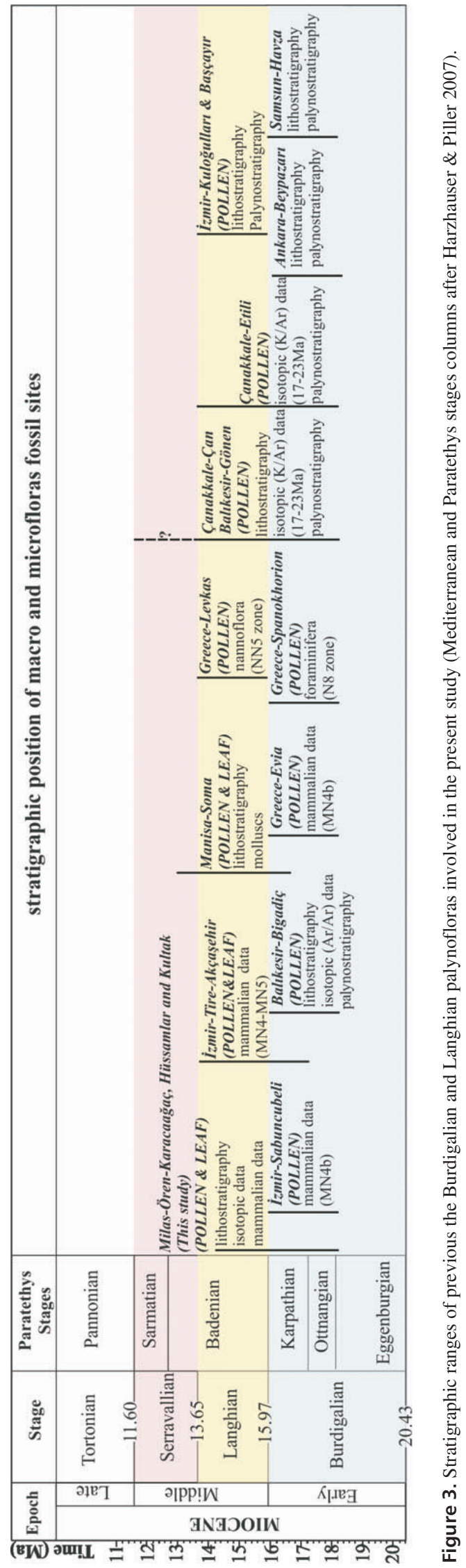




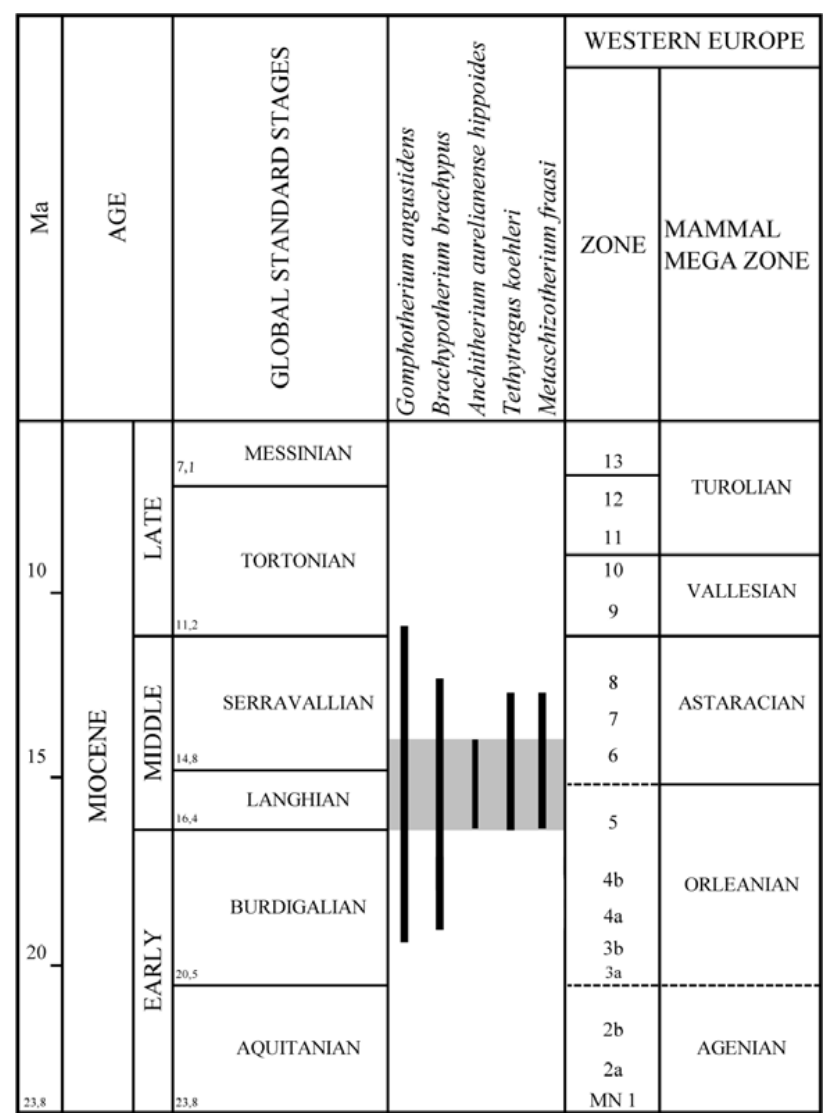

Figure 4. Faunal list and stratigraphic occurrences of the Kultak (light grey) vertebrate assemblage.

numerical palaeoclimatic results in different regions of Turkey and Greece during the late Early and early Middle Miocene periods. In this study, a total of 15 microfloras (Kultak, Karacaağaç, Hüssamlar, Havza, Beypazarı (lower and upper coal seams), Çan, Gönen, Başçayır, Kuloğulları, Sabuncubeli in Turkey and Spanokhorion, Evia and Kolivata in Greece) are analyzed to calculate seven climate variables (Fig. 3). These are mean annual temperature (MAT), mean temperature of the coldest month (CMT), mean temperature of the warmest month (WMT), mean annual precipitation (MAP), mean annual range of temperature (MART = WMT-CMT) and precipitation in the warmest month $\left(\mathrm{MAP}_{\mathrm{WARM}}\right)$, precipitation of the driest month $\left(\mathrm{MAP}_{\mathrm{DRY}}\right)$ and precipitation of the wettest month $\left(\mathrm{MAP}_{\mathrm{WET}}\right)$.

\section{The Burdigalian and Langhian palaeobiogeography in Turkey based on the vertebrates}

Although the Middle Miocene fossil localities known from Turkey are limited unlike the numerous Late Miocene localities, most of them were studied thoroughly thanks to well-organized studies dating back to early seventies
(Sickenberg et al. 1975, Gaziry 1976, Köhler 1987, Gentry 1990, Geraads et al. 1995, Kaya et al. 2001, Geraads 2003, Saraç, unpublished report, Mayda et al. 2006). The rich collections from Bursa-Paşalar, Ankara-Çandır and Ankara-İnönü localities as well as the remarkable İzmirMordoğan, Çanakkale-Nebisuyu and Milas-Kultak collections were subjected of detailed systematic studies on many paleontological papers. The Kultak faunal assemblage, previously described by Kaya et al. (2001) includes Anchitherium aurelianense hippoides (Lartet), Ancylotherium (Metaschizotherium) fraasi (Koenigswald), Tethytragus koehlerae (Azanza \& Morales) and Gomphotherium sp. Recent field work in the Kultak locality has led to the discovery of additional fossils, which are under study.

The proboscidean remains, collected from the former studies were previously allocated to Gomphotherium sp. (Kaya et al. 2001). The rich proboscidean remains recovered during the latest excavations are now identified as Gomphotherium angustidens (Cuvier). G. angustidens (Cuvier) has been found in various Early and Middle Miocene localities of Eurasia, mainly from: Spain "Bunol" and "Corcoles" (MN4); Portugal "Quinta Grande" (MN4b); France "Sansan" (MN6) and Germany "Steinheim" (MN7-8) and Saudi Arabia "Al Jadidah (MN6) (Göhlich 1999). This species is also found in Anatolia, mainly from the Middle Miocene localities of Bursa-Pașalar, Muğla-Milas-Sarıçay and Çatakbağyaka, and also from the Early Miocene locality of Ankara-Kalecik-Hancili (Gaziry 1976, Mayda et al. 2006, Saraç, unpublished report, Sickenberg et al. 1975). Well-preserved rhinocerotid remains that have been unearthed from the Kultak area were identified as Brachypotherium brachypus (Lartet). B. brachypus is a common element of Middle Miocene localities of Europe, such as Simorre (MN7), Sansan (MN6) and La Grive (MN7) in France, Thannhausen (MN6) and Massenhausen (MN8) in Germany (Heissig 1999). This species was found in the Middle Miocene localities of Turkey: Ankara-Çandır, Inönü-I, Tüney, Muğla-Yenieskihisar, Çatakbağyaka, Kütahya-Sofça, Edirne-Pișmanköy, Bursa-Pașalar and Orhaneli (Saraç, unpublished report; Fig. 4). B. brachypus is a short-legged rhino of hippo-like proportions, adapted to subtropical forested habitats and nearby lakes and rivers (Fortelius 1990). It has brachydont cheek teeth indicating a soft diet. However, the wear patterns of teeth indicate intermediate diet between browser and graser (Fortelius 1990). Comparing with the other Turkish and European samples, Brachypotherium materials from Kultak appear to be slightly larger. This feature shows that our sample is more advanced in terms of evolution than the classical forms of this species. G. angustidens remains from Kultak are morphologically identical with the Turkish and European Middle Miocene samples and but distinguished from the Early Miocene forms by its relatively simple molar pattern and larger size. Tethytragus 

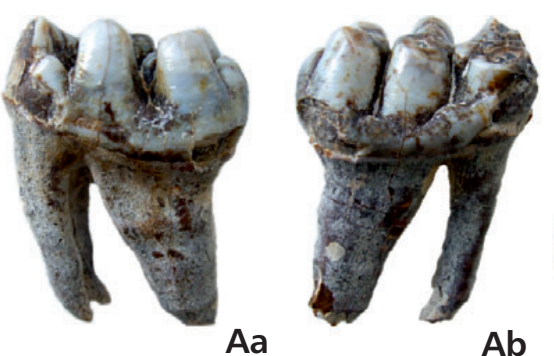

$\mathrm{Ab}$
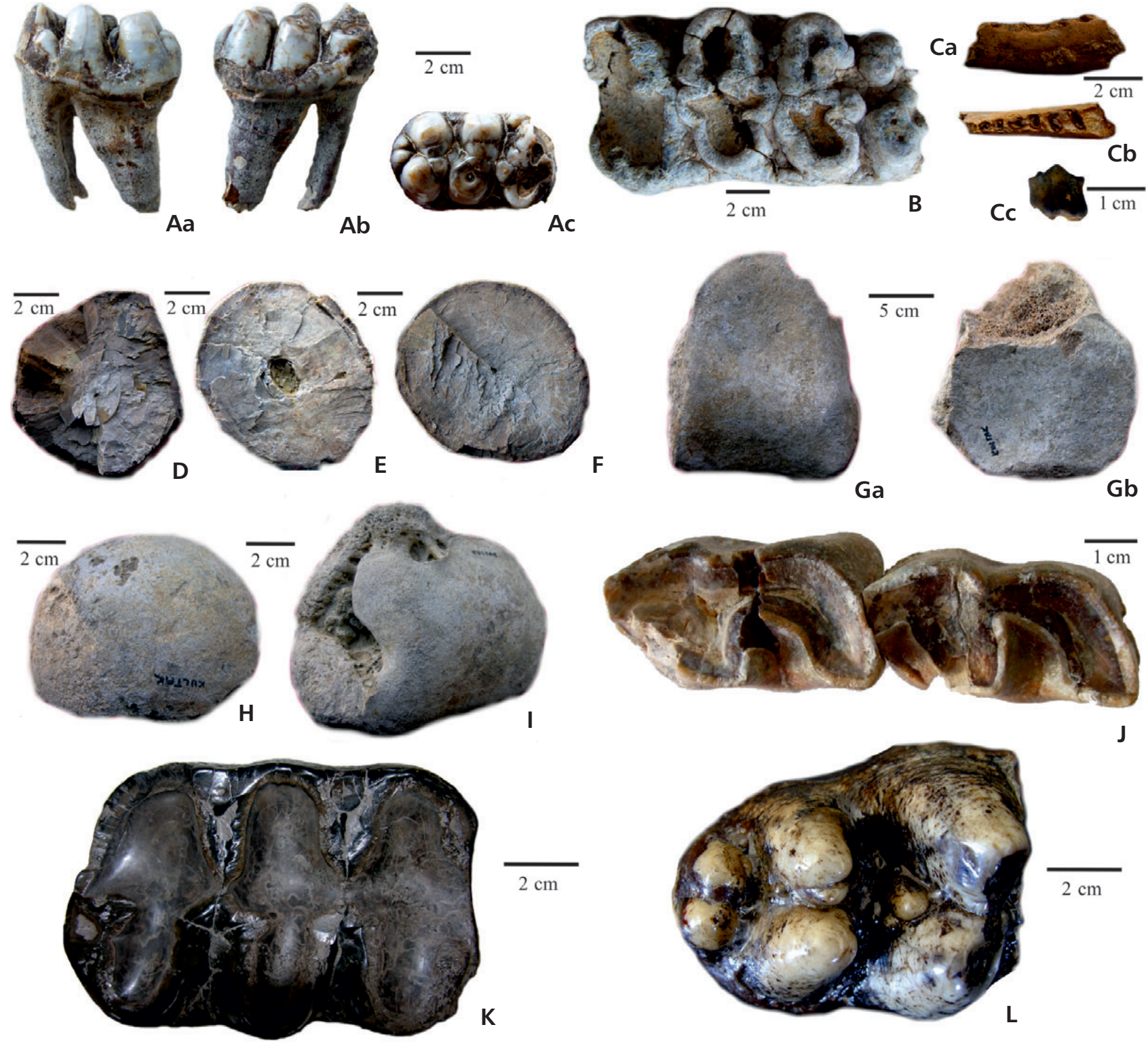

Figure 5. Mammalian fossils collected from the Hüssamlar (K, L) and $\operatorname{Kultak}(\mathrm{A}-\mathrm{J})$ localities. • A, B, D-F - Gomphotherium angustidens: lower right $\mathrm{m} 1$ (Aa - lingual view, $\mathrm{Ab}$ - labial view, Ac - occlusal view); lower left $\mathrm{m} 3$ (B - occlusal view); upper tusk fragments in cross-section (D, E - proximal view, F - distal view). $\bullet \mathrm{C}-$ Tethytragus koehlerae; left hemimandible with $\mathrm{p} 4(\mathrm{Ca}$-lingual view, $\mathrm{Cb}, \mathrm{Cc}-$ labial view). $\bullet \mathrm{G}-\mathrm{I}-$ Gomphotherium angustidens; right cuneiform ( $\mathrm{Ga}$ - proximal view, $\mathrm{Gb}$ - distal view), $\mathrm{H}$ - caput femoris, $\mathrm{I}$ - right astragalus (occlusal view). $\bullet \mathrm{J}-$ Brachypotherium brachypus: lower right $\mathrm{m} 1-2$ (occlusal view). $\bullet \mathrm{K}, \mathrm{L}-$ Gomphotherium angustidens: $\mathrm{K}$ - upper right $\mathrm{M} 2$, occlusal view; $\mathrm{L}-$ lower right $\mathrm{m} 3$, oclusal view.

koehlerae from the Kultak fauna (Kaya et al. 2001) is a species typical for the Middle Miocene and it has previously been known from Bursa-Pașalar, Muğla-Sarıçay, and Ankara-Çandır and Inönü localities (Köhler 1987, Gentry 1990, Geraads et al. 1995, Geraads 2003; Figs 4, 5).

Besides the systematic and taxonomic part, we have focused on the faunal similarity of Middle Miocene localities from Turkey and Europe, at genus level only, using the UPGMA (unweighted pair group method with arithmetic mean) cluster algorithm method on similarity indices based on the presence/absence data (Fig. 6A, B). Over 50 taxa from the following mammalian faunas are analyzed by the Jaccard Index (Jaccard 1908) as a distance measure to examine palaeocommunity integrity, taking into consideration only the sites with at least ten species (except Çanakkale-Nebisuyu locality) that we also retained for this analysis. The sites from Turkey are Bursa-Pașalar (MN6, NW Anatolia), Ankara-Çandır (MN6, Central Anatolia), İzmir-Mordoğan (MN6, Western Anatolia); Ankara-İnönü (MN6, Central Anatolia), Muğla-Kultak (MN6; SW Anatolia), Nebisuyu (MN6-7/8, NW Anatolia), Muğla-Çatakbağyaka (MN6-7/8, SW Anatolia) and from 


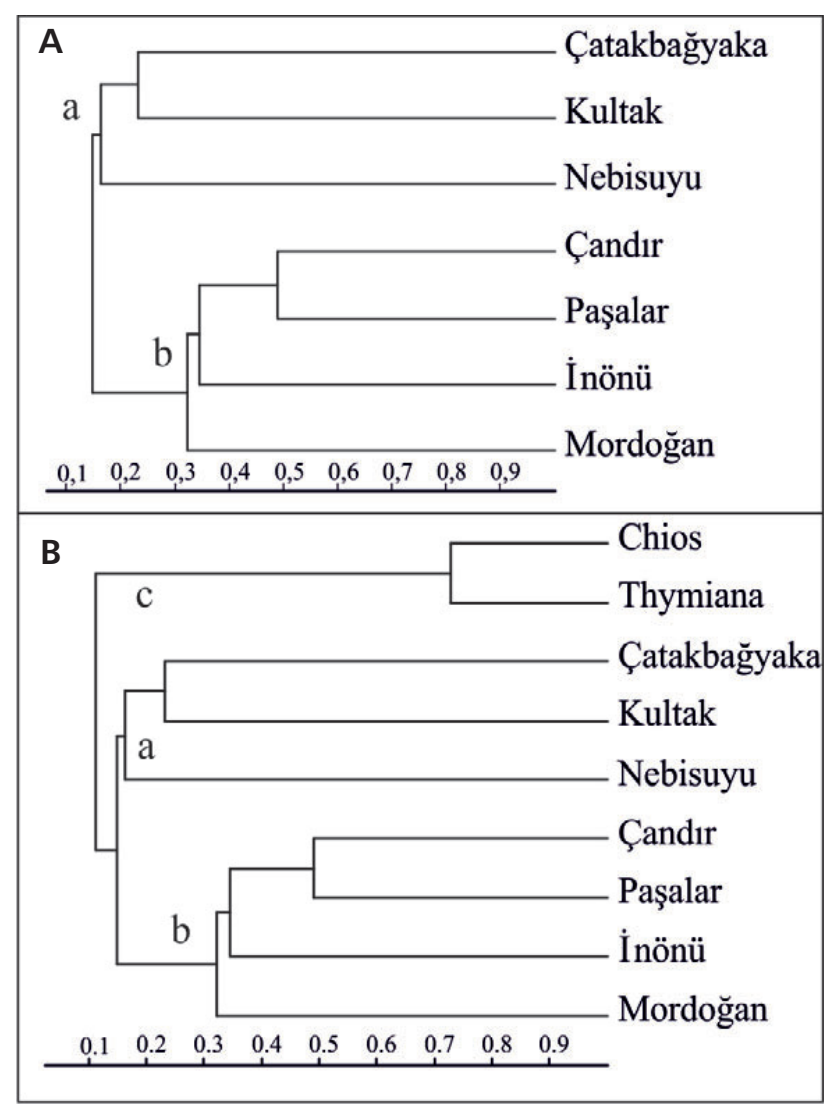

Figure 6. Cluster Analysis on presence/absence data at the genus level, using Jaccard's similarity index on Middle Miocene sites. A - Turkish, B - Greek and Turkish.

Greece Chios (MN5) and Thymiana (MN5) (Casanovas-Vilar et al. 2011). The Fig. 6 summarizes the result of the analysis carried out on the Middle Miocene taxa (Fig. 6A, B). Considering the Fig. 6A, the dendrogram based on the Jaccard index has grouped two major clusters: (1) the Central and NW Anatolian localities (BursaPașalar, Ankara-Çandır, İnönü; cluster A) and (2) SW Anatolian localities (the others; cluster B). The first group is clearly separated from the second group except for the İzmir-Mordoğan site, which seems to close to Ankara-Inönü and Çandır respectively. Moreover, there is a clear separation between the Anatolian faunas correlated to MN6, MN6-7/8 and Greek faunas (Fig. 6B). Bursa-Pașalar and Ankara-Çandır localities match together as a result of high faunal similarity and Ankara-Inönü and İzmirMordoğan localities follow this conclusion. This arrangement of Kultak, Çatakbağyaka and Nebisuyu localities in the upper cluster (Fig. 6A) also marks a higher bovid diversity than the rest of the other Turkish faunas, which points out that a more open environment was dominant during the Middle Miocene in Central Anatolia.

Andrews \& Kelley (2007) suggest a subtropical woodland or forest environment incorporating open areas with abundant ground vegetation for the Middle Miocene at Bursa-Pașalar. Geraads et al. (2003) proposed a relatively dry, seasonal subtropical woodland habitat for Ankara-Çandır and Bursa-Pașalar and emphasized that Ankara-Çandır had a dominant open country biotope and Ankara-İnönü had an even more open environment compared to the former sites. This type of environment, which is lately documented at İzmir-Mordoğan (Geraads et al. 2002), is composed of a mixture of woodland and grassland habitats, which were widespread in the western part of Anatolia. Çanakkale-Nebisuyu differs significantly from the former localities by the absence of open environment elements, such as bovids. Chalicotherium and Anchitherium are regarded as being moist forest inhabitants. This is also consistent with the existence of more or less the same taxa at Kultak and Çatakbağyaka. Besides, the new Kultak rhino record, Brachypotherium brachypus, which is a short-legged brachydont rhino of hippo-like proportions, usually assumed to inhabit subtropical forested habitats and nearby lakes and rivers (Fortelius 1990). In summary, the mammalian data argue for the existence of a humid palaeoclimate in SW and NW Anatolia. On the contrary, Central Anatolia was under the influence of a dry phase throughout the Langhian.

The field work around the Hüssamlar lignite deposits in the last couple of years provided limited assemblage of a mammalian fauna in which two species can be determined. The first one is the common proboscidean, Gomphotherium angustidens, which is already recorded in Kultak. However, the Hüssamlar material differs from the Kultak one in its slightly smaller size and archaic occlusal pattern of teeth. The other record is a small European brachypothere Prosantorhinus sp., which also makes its first appearance in Turkey. According to Cerdeno (1996) this genus has a quite widespread distribution with two species, Prosantorhinus germanicus and Prosantorhinus douvelli in Western and Central Europe during the late Early (MN3) to latest Middle Miocene (MN7/8). We may well add the recently described Prosantorhinus laubei from the well-known locality Tuchorrice (MN3) in Czech Republic to be the third species intermediate between the first two (Heissig \& Fejfar 2007). The preliminary study of Turkish material reveals morphological and metrical similarities with the largest form, Prosantorhinus douvelli from Beaugency (MN5), which hosted the last appearance of this species. These taxa indicate a humid continental environment.

Considering the preliminarily studied new material mentioned above, we may suggest an age of "MN4b-5" for Hüssamlar, which refers to a slightly older age comparing to Kultak. According to whole data gathered from the preliminary faunal studies, the same type of ecological conditions might have occurred during the Middle Miocene in the Kultak and Hüssamlar areas, although shorter premolar 
rows and more slender metapodials of Prosantorhinus douvelli compared to Brachypotherium brachypus may reflect drier local conditions in Hüssamlar than in Kultak.

\section{Palynoflora of Milas-Ören Region}

In this study, three palynofloras from the Kultak, Hüssamlar and Karacaağaç localities are described. The diversity and percentages of spores are low, but the abundance of pollen is remarkable. While most the taxa are recorded in low frequencies, a few are abundant.

The Kultak microflora is characterized by the highest frequency of Laevigatisporites haardti (Polypodiaceae), Laevigatosporites gracilis (Polypodiaceae), Pityosporites microalatus (Pinaceae-Pinus haploxylon type), Momipites punctatus (Engelhardia), Momipites quietus (Engelhardia), Polyporopollenites undulosus (Ulmus), Caryapollenites simplex (Carya), Subtriporopollenites anulatus nanus (Juglandaceae), Tricolpopollenites densus (Quercus sp.), Tricolpopollenites microhenrici (Quercus), Tricolporopollenites cingulum (Castaneae), Tricolporopollenites megaexactus (Cyrillaceae), represented by the values from 5 to 20\%. Pinus haploxylon type and indeterminate Pinaceae are characterized with higher values of 5 to $10 \%$. Cupressacites cuspidateaformis (Cupressaceae) appears regularly with values of 4 to $9 \%$. Spores are represented by scarce grains of Baculatisporites primarius (Osmundaceae), Verrucatosporites favus (Davaliaceae), Leiotriletes maxoides minoris (Schizaceae), Leiotriletes maxoides maxoides (Schizaceae) and Leiotriletes tranquillus (Schizaceae) (Fig. 7). Open vegetation elements, Graminidites gramineoides (Poaceae) and Umbelliferaepollenites sp. (Apiaceae), are found in minor quantities. Inaperturopollenites dubius (Cupressaceae-Taxodioidea), Polyporopollenites stellatus (Pterocarya), Triatriopollenites rurensis (Myricaceae-Myrica), Tricolpopollenites retiformis (Platanus/Salix), Tricolporopollenites pacatus (Simaroubaceae), Oleoidearumpollenites microreticulatus (Oleaceae) scarcely and Dicolpopolenites kockelii (Calamus), Zonolapollenites verrucatus (Tsuga), Inaperturopollenites polyformosus (Sequoia), Plicapollis plicatus (Juglandaceae), Quercopolllenites robur (Quercus deciduous type), Tricolpopollenites librarensis librarensis (Fagaceae), Tricolpopollenites librarensis fallax (Fagaceae), Polyporopollenites undulosus (Ulmaceae-Ulmus/Zelkova), Tetracolporopollenites spp., Cyperaceae sp., and Avicennia rarely or sporadically recorded in this microflora (Fig. 7, Table 1).

The diversity and percentages of spores (Baculatisporites primarius (Osmundaceae) and Leiotriletes sp. (Schizaceae)) in the Karacaağaç palynoflora are low, except for Laevigatisporites haardti (Polypodiaceae), which is recorded abundantly in all samples (20-40\%). Indeterminate Pinaceae and Pinus haploxylon type species are more abundant (10-25\%). The pollen of Inaperturopollenites dubius (Taxodioidea), Tricolpopollenites microhenrici (Quercus) and Polyvestibulopollenites verus (Alnus) appear in high amounts (5-15\%). Gymnosperm pollen of Pityosporites labdacus (Pinus silvestris type), Pityosporites libellus (Podacarpus), Pityosporites macroinsignis (Pinus haploxylon type), Cedripites miocenicus (Cedrus), Cathaya sp., Cupressacites cuspidateaformis (Cupressaceae) are also less abundantly recorded (2-5\%). Herbs such as Graminidites gramineoides (Poaceae), Ephedripites spp. (Ephedraceae), Periporopollenites multiporatus (Amaranthaceae-Chenopodiaceae), Cichoreacidites sp. (Asteraceae-Cichorioideae-Liguliflorae type) and Tricoporopollenites sp. (Asteraceae-AsteroideaeTubulifloreae type) are scarcely observed (1-4\%). Betulopollenites betuloides (Betulaceae), Quercopollenites robur (Quercus deciduous type), Tricolpopollenites densus (Quercus), Arecipites sp. (Arecaeae), Polyporopollenites undulosus (Ulmaceae-Ulmus), Triatriopollenites rurensis (Myricaceae-Myrica), Triatriopollenites coryphaeus (Engelhardia), Momipites punctatus (Engelhardia), Momipites quietus (Engelhardia), Lonicerapollis sp. (Lonicera), Tricolporopollenites. megaexactus exactus and brühlensis (Cyrillaceae), Polycolporopollenites sp., Inaperturopollentites laevigatus (Cupressaceae-Taxodioidea), Sparganiapollenites neogenicus (Sparganiaceae), Liriodendrioipollis semiverrucatus (Magnoliaceae-Liriodendron), Polygalacidites sp. (Polygalaceae) and Magnolipollis sp. (Magnoliaceae-Magnolia) is scarcely or rarely present in the Karacaağaç palynoflora (Fig. 8, Table 1).

The high percentages of ferns in the Hüssamlar palynospectra [Laevigatisporites haardti (Polypodiaceae), Sparganiapollenites neogenicus (Sparganiaceae), and Baculatisporites primarius (Osmundaceae), 5-30\%] recall that of the Karacaağaç palynoflora. Gymnosperm pollen Pityosporites microalatus (Pinus haploxylon type), Cathaya and indeterminate Pinaceae - achieve their highest percentages of 10-43\%. The highest abundance of the Tricolpopollenites microhenrici (Quercus) and Inaperturopollenites hiatus (Taxodioidea) is observed in this palynoflora (10-33\%). The pollen of Inaperturopollenites dubius (Taxodioidea), Polyvestibulopollenites verus (Alnus), Tricolporopollenites cingulum oviformis (Castanea), Ineperturopollenites laevigatus (Taxodioidea) are observed in reliable percent (2-15\%). Grassland species (Graminidites gramineoides (Poaceae) and Periporopollenites multiporatus (Amaranthaceae-Chenopodiaceae) are not various in this palynoflora but these are regularly present (1-5\%). Quercopollenites robur (Quercus deciduous type), Tricolpopollenites densus (Quercus), Cupressacites cuspidateaformis (Cupressaceae), Momipites punctatus (Engelhardia), Tricolporopollenites megaexactus exactus and brühlensis (Cyrillaceae), Tricolporopollenites microreticulatus (Oleaceae) barely (3-5\%) and 
Table 1. Ecological requirement and climatic character of extant taxa represented by sporomorphs of the Kultak, Karacaağaç and Hüssamlar regions (i.e. Kovar-Eder 1987; Planderová 1991; Nagy 1990, 1999, 1992; Akgün \& Akyol 1999).

\begin{tabular}{|c|c|c|c|c|}
\hline Taxa & & Preferable habitat & Climatic distribution & $\begin{array}{l}\text { Deciduous/evergreen/ } \\
\text { sclerophyllous trees }\end{array}$ \\
\hline \multicolumn{5}{|l|}{ Spores } \\
\hline Schizaeaceae-Lygodium & $\begin{array}{l}\text { Leiotriletes sp., L. maxoides } \\
\text { minoris, L. microadrienni, } \\
\text { L. traquillus }\end{array}$ & Cosmopolitan & Subtropical to tropical & Fern \\
\hline Polypodiaceae-Pteridoidreae & $\begin{array}{l}\text { Laevigatosporites haardti, } \\
\text { L. gracilis }\end{array}$ & Cosmopolitan & Cosmopolitan & Fern \\
\hline Davaliaceae & Verrucatosporites favus & Cosmopolitan & Subtropical to tropical & Fern \\
\hline Osmundaceae-Osmunda & Baculatisporites primarius & Cosmopolitan & Cosmopolitan & Fern \\
\hline \multicolumn{5}{|l|}{ Pollen } \\
\hline \multicolumn{5}{|l|}{ Gymnosperm } \\
\hline Pinus (haploxylon type) & $\begin{array}{l}\text { Pinuspollenites microalatus, } \\
\text { Pinuspollenites macroinsignis }\end{array}$ & Conifer forest & Warm temperate & Evergreen \\
\hline Pinus (silvestris type) & Pinuspollenites labdacus & Conifer forest & Temperate & Evergreen \\
\hline Pinus & Pityosporites spp. & Conifer forest & Temperate & Evergreen \\
\hline Podocarpaceae-Podocarpus & Podacarpidites libellus & Conifer forest & Subtropical to tropical & Evergreen \\
\hline Tsuga & Zonolapollenites verrucatus & Conifer forest & Subtropical to tropical & Evergreen \\
\hline Cedrus & Cedripites miocaenicus & Conifer forest & & Evergreen \\
\hline Cathaya & Cathayapollis sp. & Conifer forest & & Evergreen \\
\hline Cupressaceae-Taxodioideae & $\begin{array}{l}\text { Cupressacites cuspidataeformis, } \\
\text { Inaperturopollenites dubius }\end{array}$ & Conifer forest & $\begin{array}{l}\text { Warm temperate to } \\
\text { temperate }\end{array}$ & Evergreen/deciduous \\
\hline Taxodioideae & $\begin{array}{l}\text { Inaperturopollenites laevigatus, } \\
\text { Inaperturopollenites hiatus }\end{array}$ & Swamp forest & $\begin{array}{l}\text { Warm temperate to } \\
\text { temperate }\end{array}$ & Evergreen/deciduous \\
\hline Ephedraceae-Ephedra & Ephedripites sp. & Herbs and shrubs & Temperate & Shrub \\
\hline \multicolumn{5}{|l|}{ Angiosperm } \\
\hline \multicolumn{5}{|l|}{ Monocotyledoneae Pollen } \\
\hline Poaceae (= Gramineae) & $\begin{array}{l}\text { Graminidites gramineoides, } \\
\text { Graminidites laevigatus }\end{array}$ & Herbs and shrubs & Cosmopolitan & Shrub \\
\hline Sparganiaceae & Sparganiapollenites neogenicus & Aquatic vegetation & Temperate & Aquatic plant \\
\hline Cyperaceae & Cyperaceae sp. & Aquatic vegetation & Cosmopolitan & Aquatic plant \\
\hline Nymphaeaeae & $\begin{array}{l}\text { Nymphaepollenites minor, } \\
\text { Monogemmites pseudosetarius }\end{array}$ & Aquatic vegetation & Cosmopolitan & Aquatic plant \\
\hline Cycadaceae-Cycas & Cycadopites spp. & Conifer forest & Subtropical to tropical & Evergreen \\
\hline Palmea & Monocolpopollenites triangulus & $\begin{array}{l}\text { Evergreen and deciduous } \\
\text { mixed forest }\end{array}$ & Subtropical to tropical & Evergreen \\
\hline Arecaeae & Arecipites sp. & $\begin{array}{l}\text { Evergreen and deciduous } \\
\text { mixed forest }\end{array}$ & Subtropical to tropical & Evergreen \\
\hline Magnoliaceae-Magnolia & Magnolipollis sp. & Herbs and shrubs & Subtropical to tropical & ?Evergreen \\
\hline Magnoliaceae-Liriodendron & Liriodendrioipollis semiverrucatus & $\begin{array}{l}\text { Evergreen and deciduous } \\
\text { mixed forest }\end{array}$ & Subtropical to tropical & ?Evergreen \\
\hline \multicolumn{5}{|l|}{ Dicotyledoneae Pollen } \\
\hline Myricaceae-Myrica & Triatriopollenites rurensis & Swamp forest & Warm temperate & Evergreen \\
\hline Juglandaceae-Engelhardtia & $\begin{array}{l}\text { Momipites punctatus, Momipites } \\
\text { quietus, Triatriopollenites } \\
\text { coryphaeus, Plicapollis plicatus }\end{array}$ & $\begin{array}{l}\text { Evergreen and deciduous } \\
\text { mixed forest }\end{array}$ & Subtropical to tropical & Evergreen \\
\hline Betulaceae & Betulapollenites betuloides & $\begin{array}{l}\text { Evergreen and deciduous } \\
\text { mixed forest }\end{array}$ & Temperate & Deciduous \\
\hline Carya Juglandaceae & $\begin{array}{l}\text { Subtriporopollenite simplex, } \\
\text { Subtriporopollenites anulatus nanus }\end{array}$ & Riparian forest & Temperate & Deciduous \\
\hline Myrtaceae & Myrtaceoidites mesonensus & $\begin{array}{l}\text { Evergreen and deciduous } \\
\text { mixed forest }\end{array}$ & Subtropical to tropical & ?Evergreen \\
\hline
\end{tabular}


Table 1. continued

\begin{tabular}{|c|c|c|c|c|}
\hline Taxa & & Preferable habitat & Climatic distribution & $\begin{array}{l}\text { Deciduous/evergreen/ } \\
\text { sclerophyllous trees }\end{array}$ \\
\hline Calamus & Dicolpopollis kockelii & Swamp vegetation & Subtropical to tropical & ?Evergreen \\
\hline Betulaceae-Alnus & Polyvestibulopollenites verus & Riparian forest & Temperate & Deciduous \\
\hline Ulmaceae-Ulmus & Polyporopollenites undulosus & Riparian forest & Temperate & Deciduous \\
\hline Pterocarya & Polyporopollenites stellatus & $\begin{array}{l}\text { Evergreen and deciduous } \\
\text { mixed forest }\end{array}$ & Warm temperate & \\
\hline Fagaceae-Quercus & $\begin{array}{l}\text { Tricolpopollenites microhenrici, } \\
\text { Quercus robur (deciduous type), } \\
\text { Tricolpopollenites densus, Quercus } \\
\text { sp. (evergreen type), } \\
\text { Tricolpopollenites liblarensis }\end{array}$ & $\begin{array}{l}\text { Evergreen and deciduous } \\
\text { mixed forest }\end{array}$ & $\begin{array}{l}\text { Warm temperate to } \\
\text { temperate }\end{array}$ & Deciduous/evergreen \\
\hline Aceraceae & Aceripollenites striatus & $\begin{array}{l}\text { Evergreen and deciduous } \\
\text { mixed forest }\end{array}$ & $\begin{array}{l}\text { Warm temperate to } \\
\text { temperate }\end{array}$ & Deciduous \\
\hline Platanus & Tricolporopollenites retiformis & Riparian forest & Temperate & Deciduous \\
\hline Salix & Tricolporopollenites retiformis & Riparian forest & Temperate & Deciduous \\
\hline Castanea & $\begin{array}{l}\text { Tricolporopollenites cingulum } \\
\text { oviformis }\end{array}$ & $\begin{array}{l}\text { Evergreen and deciduous } \\
\text { mixed forest }\end{array}$ & Warm temperate & Deciduous \\
\hline Simaroubaceae & Tricolporopollenites pacatus & $\begin{array}{l}\text { Evergreen and deciduous } \\
\text { mixed forest }\end{array}$ & Subtropical to tropical & Evergreen \\
\hline Cyrillaceae & $\begin{array}{l}\text { Tricolporopollenites megaexactus } \\
\text { exactus, T. megaexactus brühlensis }\end{array}$ & $\begin{array}{l}\text { Evergreen and deciduous } \\
\text { mixed forest }\end{array}$ & Subtropical to tropical & Evergreen \\
\hline Nyssaceae- $N y s s a$ & Tricolporopollenites kruschi & Swamp forest & Subtropical to tropical & Cosmopolitan tree \\
\hline Oleaceae-Olea sp. & $\begin{array}{l}\text { Tricolporopollenites } \\
\text { microreticulatus, } \\
\text { Oleoidearumpollenites } \\
\text { microreticulatus }\end{array}$ & $\begin{array}{l}\text { Evergreen and deciduous } \\
\text { mixed forest }\end{array}$ & Subtropical to tropical & Evergreen \\
\hline Sapotaceae & Tetracolporopollneits biconus & $\begin{array}{l}\text { Evergreen and deciduous } \\
\text { mixed forest }\end{array}$ & Subtropical to tropical & Evergreen \\
\hline Avicennia & Avicennia & Back mangrove & Subtropical to tropical & Evergreen \\
\hline Lonicera & Lonicerapollis sp. & Herbs and shrubs & Temperate to tropical & Sclerophyllous \\
\hline $\begin{array}{l}\text { Asteraceae, Asteroideae- } \\
\text { Tubulifloreae type Asteraceae, } \\
\text { Cichorioideae-Liguliflorae type }\end{array}$ & $\begin{array}{l}\text { Tricolporopollenites spp. } \\
\text { tubulifloralliguliflora types }\end{array}$ & Herbs and shrubs & Cosmopolitan & Shrub \\
\hline Polygalaceae & Polygalacidites sp. & Herbs and shrubs & Cosmopolitan & $\begin{array}{l}\text { Cosmopolitan } \\
\text { tree/shrub/herb }\end{array}$ \\
\hline Umbelliferae (= Apiaceae) & Umbelliferaepollenites sp. & Herbs and shrubs & Cosmopolitan & $\begin{array}{l}\text { Cosmopolitan } \\
\text { tree/shrub/herb }\end{array}$ \\
\hline Amaranthaceae-Chenopodioideae & Periporopollenites multiporatus & Herbs and shrubs & Cosmopolitan & $\begin{array}{l}\text { Cosmopolitan } \\
\text { shrub/herb }\end{array}$ \\
\hline
\end{tabular}

Triatriopollenites rurensis (Myrica), Subtriporopollenites simplex (Carya), Subtriporopollenites anulatus nanus (Juglandaceae), Momipites quietus (Engelhardia), Polyporopollenites undulosus (Ulmus), Tricolpopollenites retiformis (Platanus/Salix) rarely (1-3\%) recorded in the Hüssamlar palynospectra (Fig. 9, Table 1).

\section{Palaeovegetation}

In the hinterland of the Kultak locality, a broad-leaved evergreen forest, represented by Myrica, Cyrillaceae, Sapotaceae, Castanea, Engelhardia and Gleicheniaceae was widespread in the lowland area. In this vegetation belt, swamp forests were also well developed during the late Burdigalian-Langhian period. Its components (Sequoia, Cupressaceae-Taxodioidea, Polypodiaceae, Davaliaceae, Gleicheniaceae, Osmundaceae, Schizaeaceae and Myrica) indicate relatively high percentages in the palynospectra. The presence of swamp vegetation, which is supported by the lowland topography and humid conditions, was confirmed by mammalian fossils. The swamp and broad-leaved evergreen forests were accompanied by the riparian forest elements such as Platanus, Salix, Ulmus and Zelkova, Carya and Pterocarya. The occurrence of Fagaceae like Castanea and Quercus (deciduous and evergreen types), 


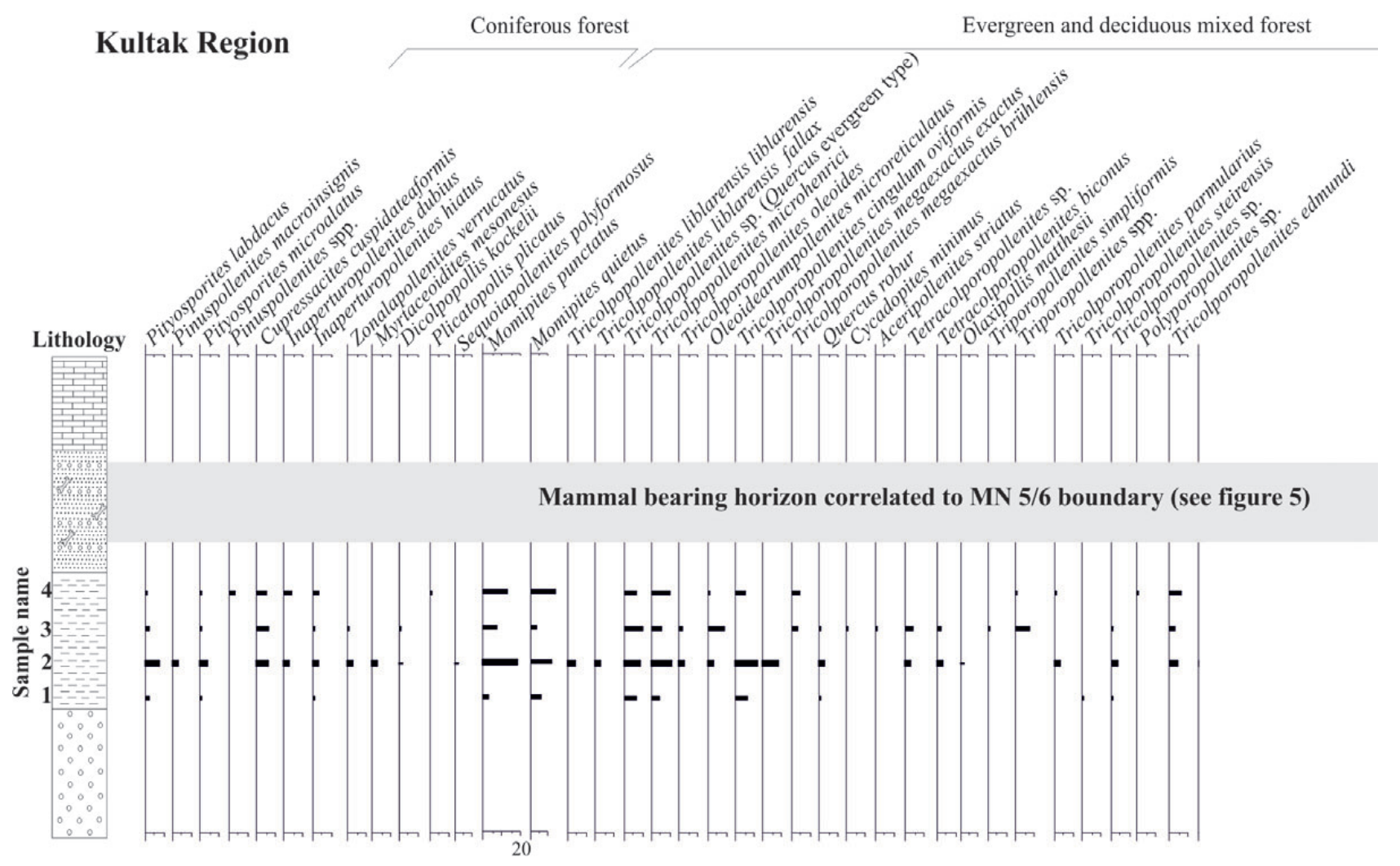

Figure 7. Detailed microfloras diagram of the studied part of the Kultak stratigraphic section. Black dots indicate percentage lower than $1 \%$.

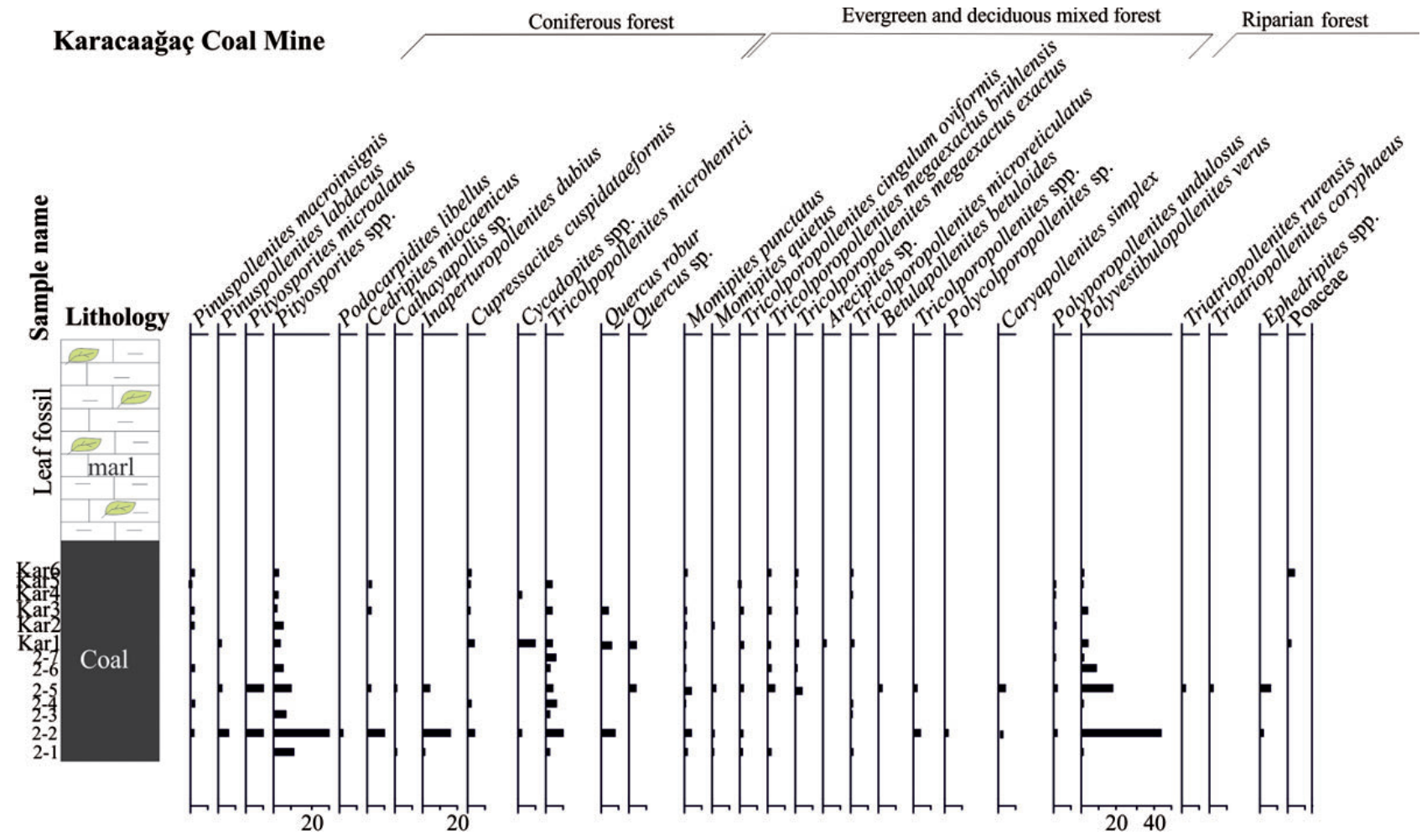

Figure 8. Detailed microfloras diagram of the studied part of the Karacaağaç stratigraphic section. Black dots indicate percentage lower than $1 \%$. 


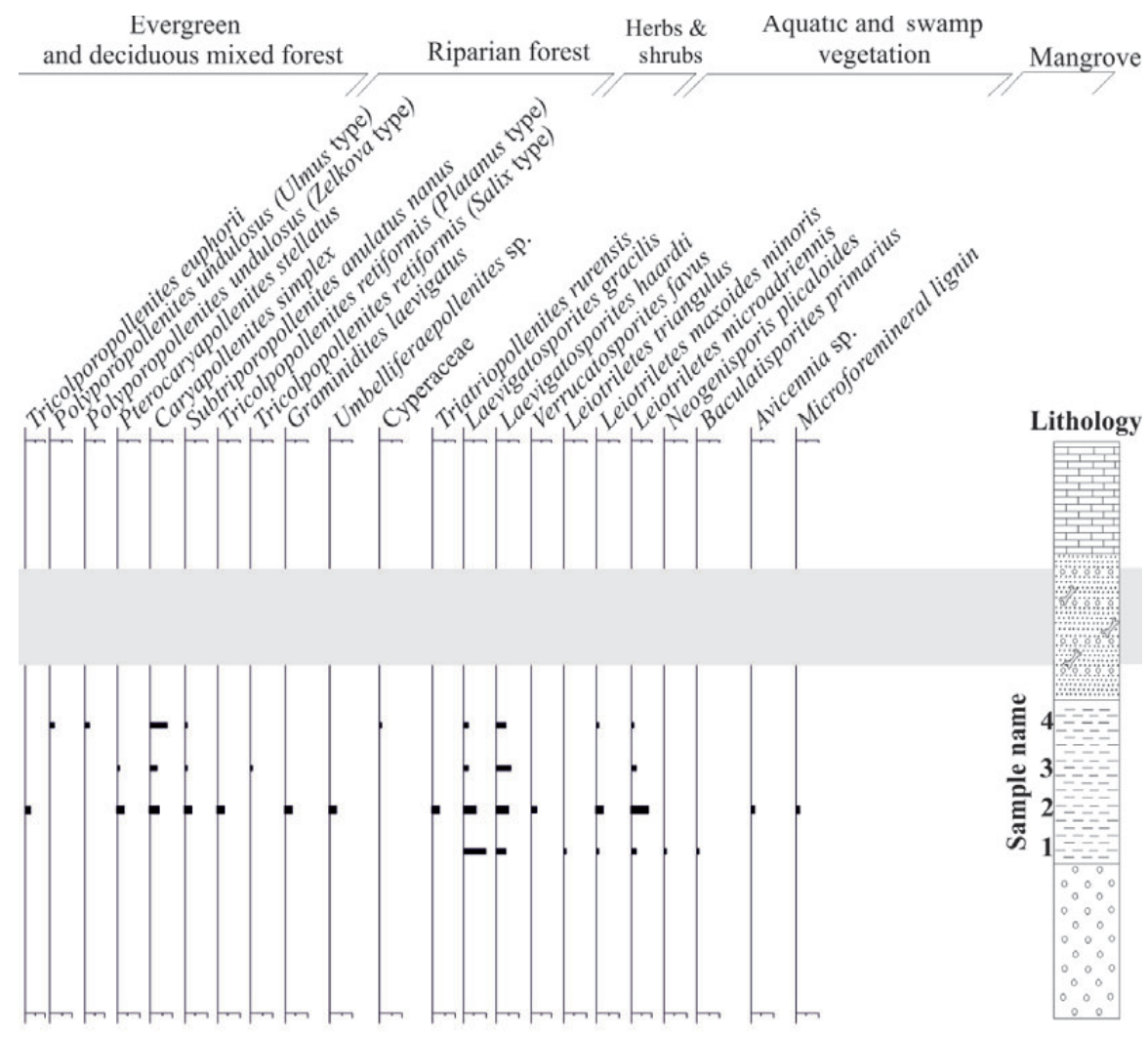

Figure 7. continued

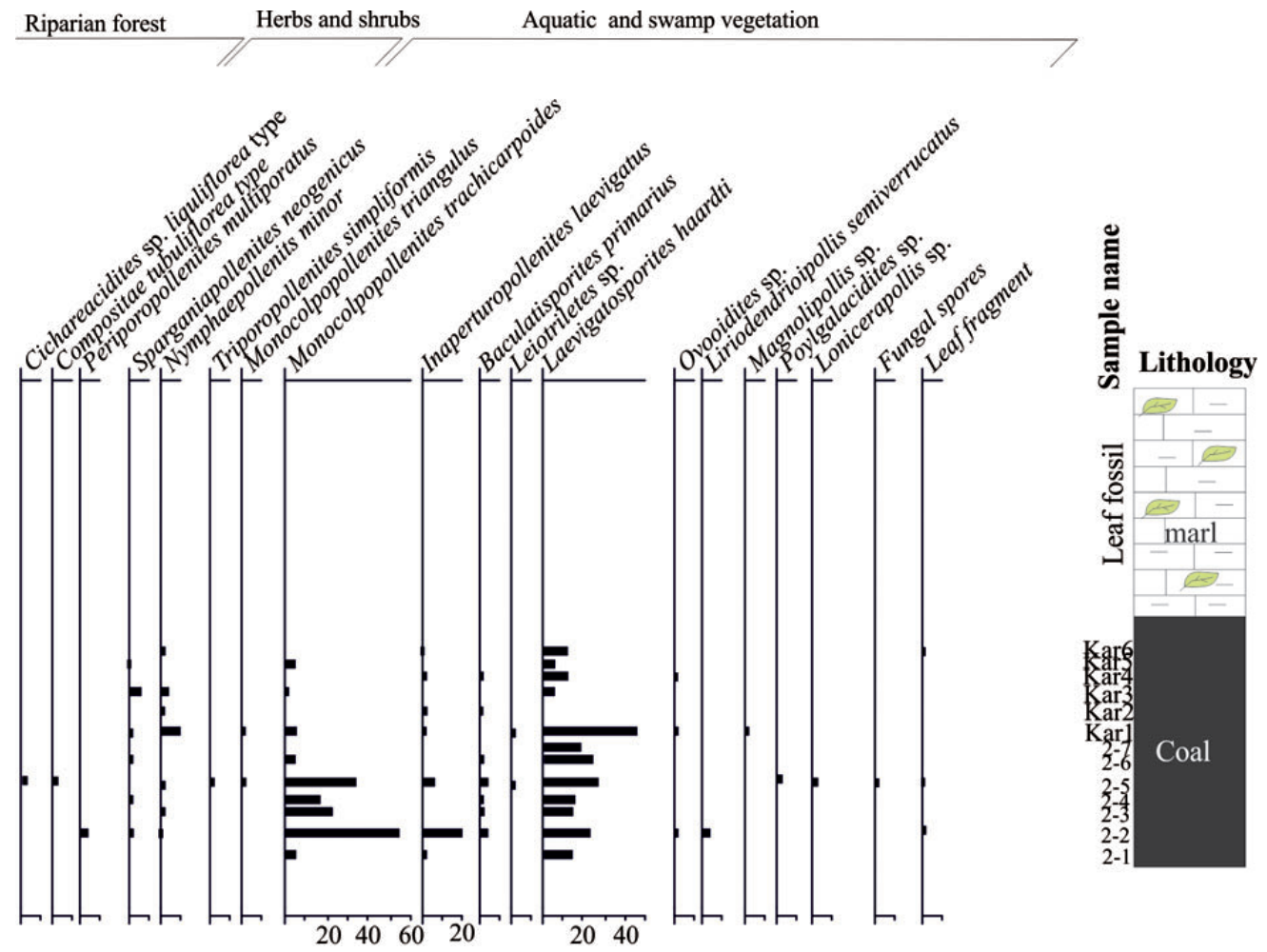

Figure 8. continued 
Hüssamlar Coal Mine

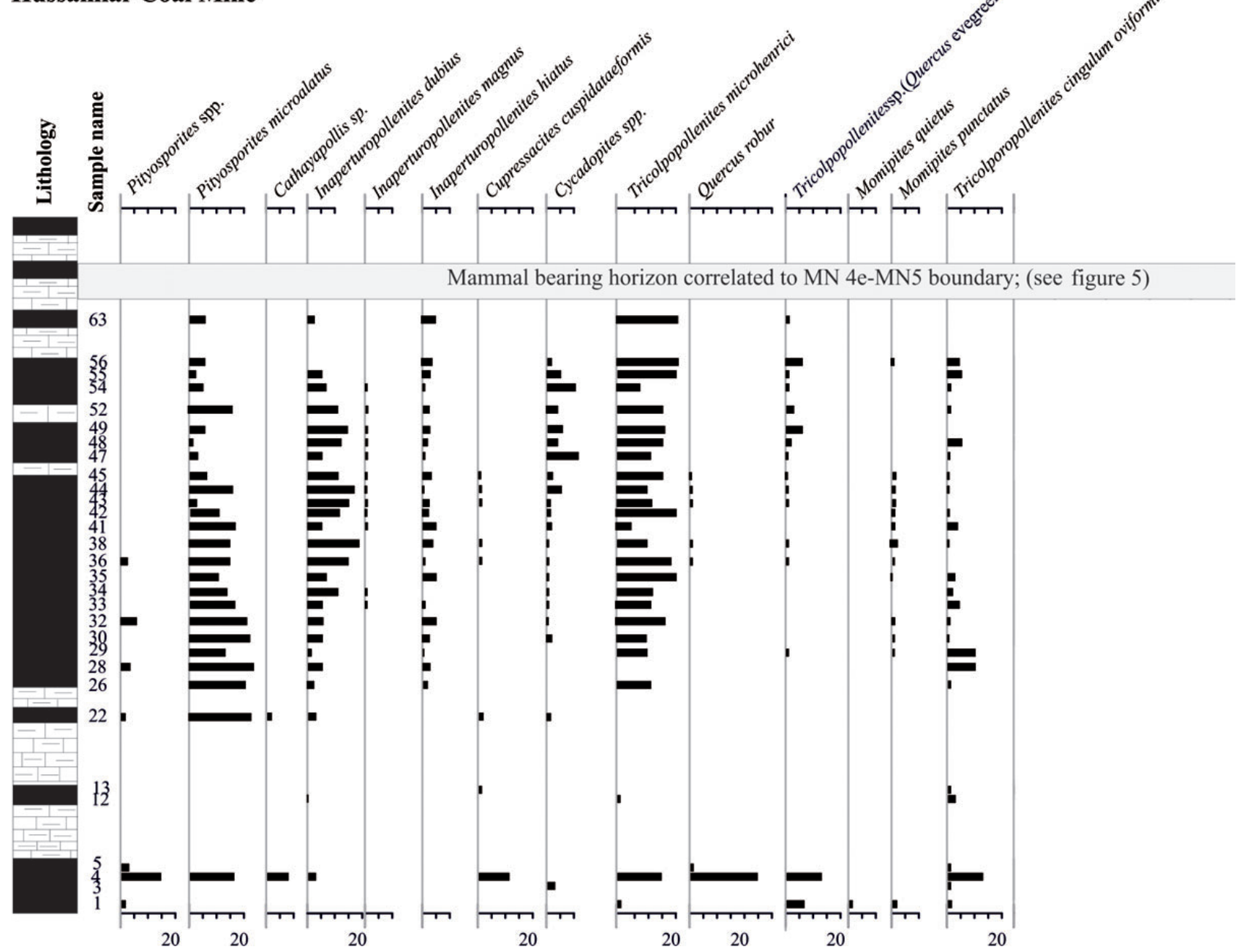

Figure 9. Detailed microfloras diagram of the studied part of the Hüssamlar stratigraphic section. Black dots indicate percentage lower than $1 \%$ and mammalian data level in the Hüssamlar section.

Juglandaceae likes Pterocarya and Engelhardia, Betulaceae, Acer, Cyrillaceae, Oleaceae and Sapotaceae indicates evergreen and deciduous mixed forests. Gymnosperm pollen mainly that of Pinus haploxylon type and other indeterminate Pinaceae are found less abundantly, presumably because of the capacity of saccate pollen for long-distance transport, and also because of differentiation of palaeotopography and/or taphonomy (Heusser 1988, Suc \& Drivaliari 1991, Cambon et al. 1997, Beaudouin 2003). Additionally, mid and high altitude elements are characterized by Pinus pollen of the diploxylon and haploxylon types and Tsuga in the Kultak locality (Fig. 7; Ivanov et al. 2012). Microforaminiferal lignin and Avicennia pollen are also recorded in the Kultak palynospectra and these palynomorphs indicate marine effect in the region during the late
Burdigalian-Langhian time interval (MN4-5 boundary). Besides, the finding of corals, bivalves, and foraminifer fossils in Kultak (Kayseri 2010, Kayseri \& Akgün 2010) strengthens the presence of marine effect.

The aquatic and swamp palaeovegetation was represented by Sparganiaceae, Nymphaeceae, Osmundaceae, Poypodiaceae, Taxodioidea, Myrica. The abundance of these taxa indicates the presence of shallow lake environments in the Karacaağaç and Hüssamlar localities during the Burdigalian-Langhian time interval. The plants of the riparian forest elements (Alnus, Ulmus and Carya) are also abundantly recorded in both palynospectras. Coniferous forest elements are recorded more abundantly in Karacaağaç and Hüssamlar microfloras, accompanied by evergreen-deciduous mixed mesophytic forest elements. This 


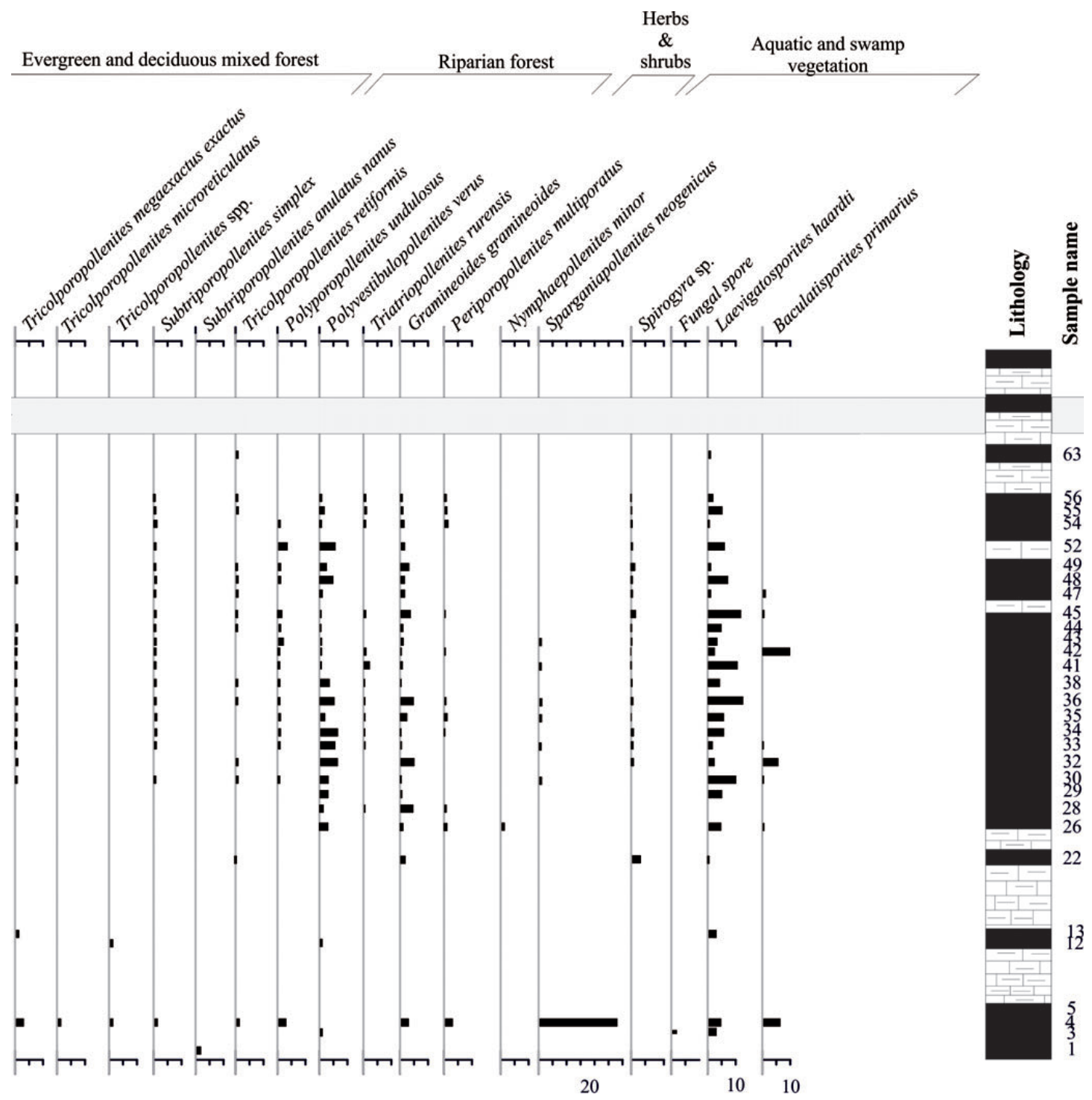

Figure 9. continued

abundance could be interpreted as the presence of high topographic areas around the lacustrine depositional area during the middle Burdigalian-Langhian period (MN4-5 boundary). Although the percentage of herb and shrubs species (i.e. Ephedraceae, Poaceae, Chenopodiaceae, Asteraceae-Asteroideae-Tubulifloreae type and Cichorioideae-Liguliflorae type) in the Hüssamlar and Karacaağaç palynospectras is low, their percents varied in all samples (Figs 8,9). This result suggests the presence of the narrow open vegetational areas at Karacaağaç and Hüssamlar throughout the middle Burdigalian-Langhian time interval. These grassland areas are also supported by the mammalian fossil records of the Hüssamlar locality.

The significant difference between the Kultak, Hüssamlar and Karacaağaç palynofloras is mainly environmental: while clastic sediments in the Kultak locality indicate deltaic conditions, the coal bearing sediments in the Hüssamlar and Karacaağaç localities were deposited in a lacustrine environment. In the Hüssamlar and Karacaağaç localities freshwater swamp was existed during the middle Burdigalian-Langhian period together with a high topographic condition surrounding of the swampy area as shown by the abundance of gymnosperm pollen. The Kultak locality is located southern to Hüssamlar and Karacaağaç, and it is characterized by the effect of brackish marine conditions. This marine condition is supported by the foraminifers, corals, bivalves, and also back mangrove plants (Fig. 10). This marine palaeoenvironmental evidence based on faunal and floral data could indicate that the land-see line in the middle Burdigalian-Langhian time could be near the Kultak locality.

In Turkey, the palynoflora of the Burdigalian- 
Table 2. $\mathrm{CA}_{\text {palynoflora }}$ results (MAT, CMT, WMT and MAP) of the Burdigalian-Langhian time interval in Turkey.

\begin{tabular}{|c|c|c|c|c|c|c|c|}
\hline Location & Climate & References & $\operatorname{MAT}\left({ }^{\circ} \mathrm{C}\right)$ & $\mathrm{CMT}\left({ }^{\circ} \mathrm{C}\right)$ & WMT $\left({ }^{\circ} \mathrm{C}\right)$ & MAP (mm) & $\operatorname{MART}\left({ }^{\circ} \mathrm{C}\right)$ \\
\hline$\geq$ Ören-Karacaağaç & Warm subtropical & This study & $17.0-18.4$ & $6.2-12.5$ & $26.5-28.1$ & $1146-1322$ & 17.95 \\
\hline 芯 Ören-Hüssamlar & & & $17.0-21.3$ & $6.2-13.3$ & $27.3-28.1$ & $1146-1322$ & 17.95 \\
\hline$\stackrel{\ddots}{\exists}$ Ören-Kultak & & & $15.7-18.8$ & $9.6-13.1$ & $24.7-27.7$ & $1122-1520$ & 13.5 \\
\hline $\begin{array}{l}\text { Ankara-Çayırhan } \\
\text { (upper coal seam) }\end{array}$ & Warm subtropical & $\begin{array}{l}\text { Güngör (1991), } \\
\text { Whateley \& Tuncalı (1995) }\end{array}$ & $16.5-20.8$ & $4.8-13.3$ or $0.9-1.1$ & $26.0-27.9$ & $735-1520$ & 17.9 or 25.95 \\
\hline $\begin{array}{l}\text { Ankara-Çayırhan } \\
\text { (lower coal seam) }\end{array}$ & & & $17.0-21.3$ & $7.7-13.3$ & $27.3-28.1$ & $1146-1322$ & 17.2 \\
\hline Samsun-Havza & Warm subtropical & $\begin{array}{l}\text { Kayseri (2002), Kayseri \& } \\
\text { Akgün (2008) }\end{array}$ & $17.2-20.8$ & $6.2-13.3$ & $27.3-27.9$ & $1217-1322$ & 17.45 \\
\hline Çanakkale-Çan & $\begin{array}{l}\text { More temperate to } \\
\text { subtropical }\end{array}$ & Ediger (1990) & $15.7-21.3$ & $9.6-13.3$ & $22.8-28.1$ & $735-1520$ & 14 \\
\hline Çanakkale-Etili & Warm subtropical & Akgün et al. (2008) & $17.2-18.4$ & $6.2-7.4$ & $27.3-27.9$ & $1146-1151$ & 20.8 \\
\hline Balıkesir-Gönen & $\begin{array}{l}\text { More temperate to } \\
\text { subtropical }\end{array}$ & Ediger (1990) & $15.7-21.3$ & $9.6-13.3$ & $22.8-28.1$ & $437-1520$ & 14 \\
\hline Balıkesir-Bigadiç & Warm subtropical & $\begin{array}{l}\text { Akyol \& Akgün (1990), } \\
\text { Akgün et al. (2007) }\end{array}$ & $17.2-21.3$ & $6.2-13.3$ & $26.5-27.9$ & $1217-1322$ & 17.45 \\
\hline Manisa-Soma & Warm subtropical & Akgün et al. (2007) & $16.5-21.3$ & $4.8-13.3$ & $26-27.9$ & $629-1520$ & 17.9 \\
\hline İzmir-Sabuncubeli & Warm subtropical & Kayseri et al. (2007) & $17.0-18.8$ & $6.2-13.1$ & $27.3-27.7$ & $1146-1322$ & 17,85 \\
\hline Aydın-Kuloğulları & Warm subtropical & Akgün et al. (2007) & $13.5-21.3$ & $1.8-13.3$ & $25.4-28.1$ & $1183-1520$ & 19.2 \\
\hline Aydın-Bașçayır & Warm subtropical & Akgün et al. (2007) & $12.9-21.7$ & $0.9-15.6$ & $23.6-28.1$ & $735-1574$ & 17.6 \\
\hline
\end{tabular}

Langhian transition is well-documented from Beypazarı-Çayırhan, Havza, Çan, Etili, Gönen, Bigadiç, Emet, Kırka and Kestelek, Sabuncubeli, Soma, Tire, Kuloğulları, Başçayır, Kultak, Hüssamlar and Karacaağaç localities. It includes thermophilous taxa (e.g. Palmae, Engelhardia, Schizaeceae, Castaneae, Cyrillaceae, Sapotaceae), which could be observed in different palaeovegetational group, e.g. swamp, mixed mesophytic forest (Ediger 1990; Gemici et al. 1991, 1992; Güngör 1991; Whateley \& Tuncalı 1995; Akgün \& Akyol 1999; Akgün et al. 2007, Kayseri et al. 2007; Kayseri \& Akgün 2008, 2010). During this time interval, swamp palaeovegetation represented with Schizaceae, Sparganiaceae, Nyssa, Taxodioidea, Myrica and the diversity fungal spores was widespread in the central part of western Anatolia. However, abundance of mid and high altitude elements such as the gymnosperm pollen (e.g. Pinus diploxylon and haploxylon types and Abies) in the northwestern Anatolia (Çan, Etili, Gönen localities) and in northern Central Anatolia (Ankara and Samsun localities) may suggest the presence of high topographies in these areas during the Burdigalian-Langhian period. In central and western Anatolia, the evergreen and deciduous mixed forests were mainly represented by Castanea and Quercus (deciduous and evergreen types), Ulmus and Zelkova, Carya, Tilia, Cyrillaceae. Elements of the riparian forest (Alnus, Simaroubaceae, Platanus and Salix) are also observed in palynospectra of all localities during this period. Besides, species of open vegetation (e.g. Asteraceae-Asteroideae-Tubulifloreae type and Cichorioideae-Liguliflorae type, Chenopodiaceae and Poaceae) are generally observed in low percentage in the palynofloras of Central and Western Anatolia.

The palynofloras of Kolivata and Spanokhorion in Greece, correlated to the latest Burdigalian (lower part of N8 zone) thanks to the planktonic foraminiferal association from the same deposits, are characterized by abundant mixed mesophytic and coniferous forests elements, i.e. Pinus spp., Pinus haploxylon group and rarely Pinus silvestris group, Quercus, Castanea (Benda et al. 1982). The swamp forest is also well developed in Kolivata-Spanokhorion as indicated by the occurrence of the Taxodioidea, Nyssa and Myricaceae. The Kolivata-Spanokhorion palynospectra also includes some open area elements represented by herb and shrubs species such as Poaceae, Asteraceae-Asteroideae-Tubulifloreae type and Cichorioideae-Liguliflorae type, Cyperaceae and Chenopodiaceae.

Another late Burdigalian palynoflora is recorded from the Marmarenia Formation in the southern part of the Aliveri Basin in the Evia Island, Greece by Reigel et al. (1989). This palynoflora is correlated to the mammalian zone MN4a and includes abundant thermophilous elements (Engelhardia, Sapotaceae, Platycarya and Palmae). Palaeovegetation also includes swamp forest elements such as Spirogyra, Cupressaceae-Taxodioidea, Cupressaceae-Sequoia, TaxodioideaGlyptostrobus and Nymphaeaceae. In Greece, Benda et al. (1982) also recorded a Langhian (NN5 zone) microflora and nannoflora at Kolivata-Levkas. This palynoflora is characterized by the abundance of mixed mesophytic forest elements such as Cyrillaceae, Engelhardia, Cupressaceae-Taxodioidea, Pinus haploxylon type and Quercus. 
Palaeoenvironment of the Karacaağaç-Hüssamlar area as indicated by palynofloras

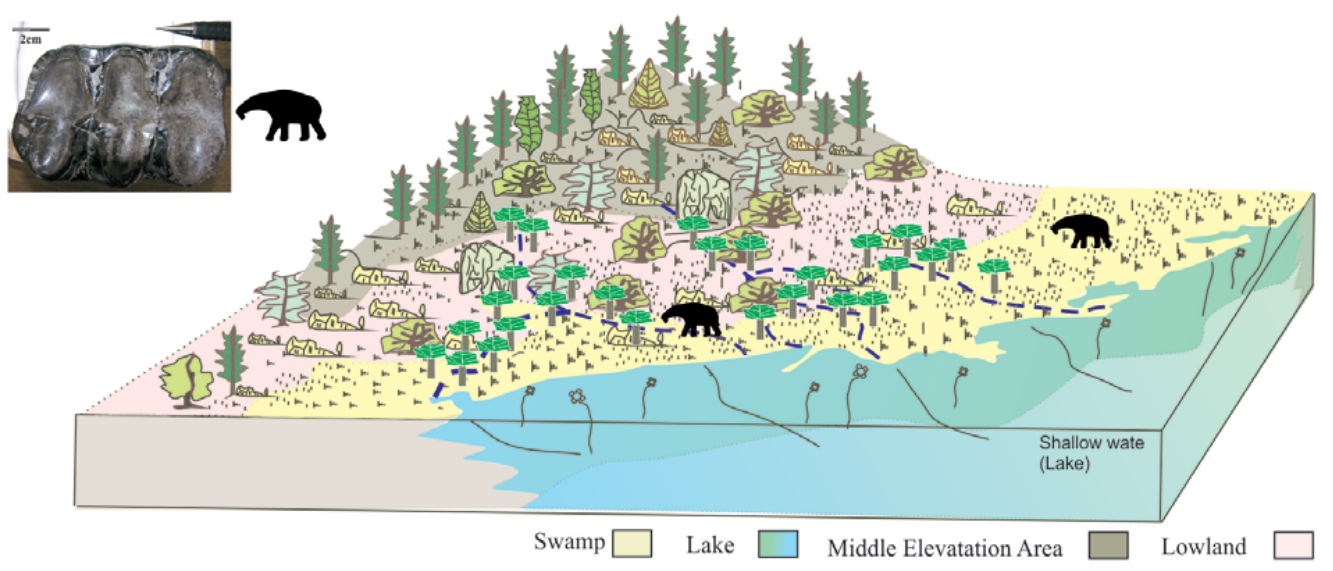

Palaeoenvironment of the Kultak area as indicated by palynofloras

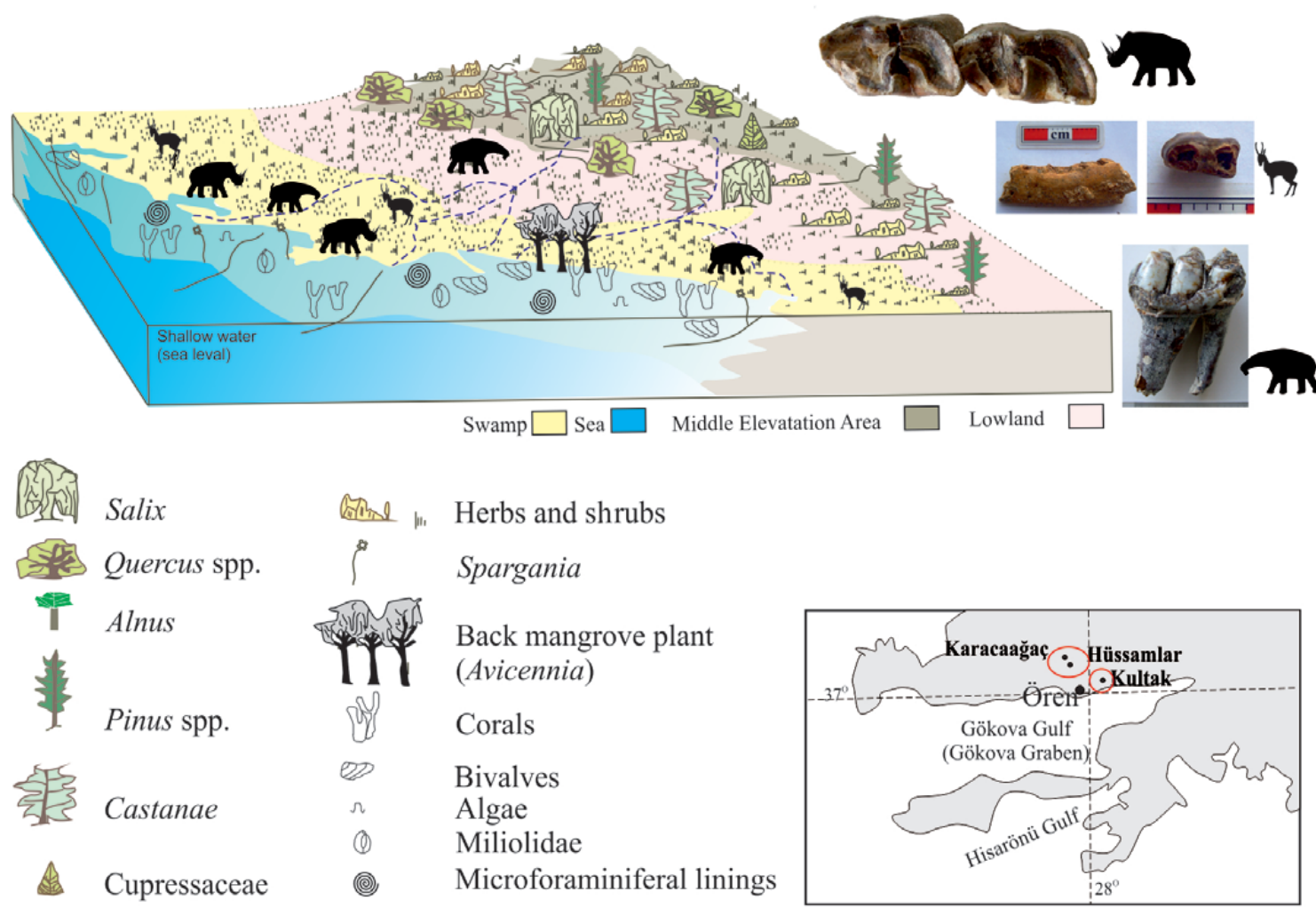

Figure 10. Reconstructed palaeobiogeography of the Kultak, Karacaağaç and Hüssamlar localities during the middle Burdigalian-Langhian period.

The herb and shrubs represented with Poaceae, Cyperaceae and Chenopodiaceae are rare in the palaeovegetation of Kolivata-Levkas ( $2 \%$ or less).

\section{Palaeoclimate and CA results}

Palaeoclimatic interpretation of the Burdigalian-Langhian palynofloras of the Kultak, Karacaağaç and Hüssamlar localities is based on the results obtained using the CA analysis method. Besides, temperature values of other localities in Anatolia and Greece are calculated using the published palynospectra of the Burdigalian-Langhian. Numeral climatic variables from Turkey and Greece are correlated with those from European countries (Germany, Serbia, Bulgaria and Ukraine). 


\section{Turkey}

The Late Burdigalian is characterized by a temperature increase, and a significantly warm climate persisted through the late Burdigalian and Langhian. This period of high temperature corresponds to the Middle Miocene Climatic Optimum, which is also globally observed based on the isotopic, faunal and floral data (e.g. Zachos et al. 2001, Mosbrugger et al. 2005). This important palaeoclimatic event in the Miocene could be evaluated using the CA method in Turkey based on the palynofloras from Karacaağaç, Kultak and Hüssamlar in the Milas region (SW Turkey, Middle Burdigalian-Langhian), from Beypazarı (latest Burdigalian), Bigadiç (latest Burdigalian), Sabuncubeli (late Burdigalian) Tire (latest Burdigalian), Soma (late Burdigalian-Langhian), Etili (late Burdigalian-Langhian), Çan and Gönen (latest Burdigalian-?Serravallian) and Başçayır and Kuloğulları (Langhian) (Table 2).

In the middle Burdigalian, the CMT value of Kultak is higher than in the other localities in Turkey. This higher value indicates the palaeoclimatic condition in the Kultak locality warmer than the others. Additionally, MART value of this locality is lower than in the other localities in Turkey and this could be interpreted as the presence of a low palaeotopographic condition in Kultak during the middle Burdigalian-Langhian time interval. Besides, the CMT and MART values of Karacaağaç and Hüssamlar localities are similar and the MART values of these localities are higher than the MART values of Kultak. This different CMT and MART values could be interpreted as indicative of different palaeogeographic conditions in the Karacaağaç, Hüssamlar and Kultak localities during the Burdigalian-Langhian period. This evidence is supported by the low altitude deltaic conditions observed in the middle Burdigalian-Langhian period in Kultak while a lowland and middle altitude area with lacustrine condition is observed in the Hüssamlar and Karacaağaç localities based on their faunal and floral fossil contents and sedimentary facies. The palynoflora of the Kultak locality reinforced this palaeoenvironmental evidence thanks to presence of plants growing in mangrove environment (Avicennia), foraminifers, bivalves and corals.

The highest MART values and lower CMT values are calculated for the Etili and Çayırhan localities and these data could be interpreted as resulting from high palaeotopographic condition in the late Burdigalian-Langhian period in these localities. Despite some environmental differences (e.g. palaeotopography, palaeogeographic position), temperature values are high, and warm subtropical climatic condition inferred from these values dominated in the all localities, and this led to the development of thermophilous plants (Engelhardia, Sapotaceae, Cyrillaceae, Avicennia, Palmae etc.).

\section{Greece}

Detailed palynological records from the Miocene of Greece were obtained by Benda (1971) and Benda et al. (1982). They observed warm subtropical palaeoclimatic conditions for the latest Burdigalian and Langhian time interval in Greece (Benda et al. 1982) based on the palynofloras, which are characterized by the thermophilous elements (e.g. Cyrillaceae, Engelhardia). Using these data, we calculated the numerical climatic values for Spanokhorion in Greece, which are the MAT 9.10-10.8 ${ }^{\circ} \mathrm{C}$ or $15.6-21.3{ }^{\circ} \mathrm{C}$, the CMT $(-2.7)-1.1^{\circ} \mathrm{C}\left(-0.8^{\circ} \mathrm{C}\right)$ or $5.0-13.3^{\circ} \mathrm{C}\left(9.15^{\circ} \mathrm{C}\right)$, the WMT $24.7-43.0{ }^{\circ} \mathrm{C} \quad\left(33.85{ }^{\circ} \mathrm{C}\right)$, the MAP 823.0-1520.0 $\mathrm{mm}$ and the MART $34.65^{\circ} \mathrm{C}$ or $24.7^{\circ} \mathrm{C}$. The presence of two intervals of the MAT, CMT and MART could be interpreted as due to two different palaeotopographic conditions at Spanokhorion during the late Burdigalian period. The palaeogeography of this period supports this interpretation (Pindos uplift and opening of the Ionian Basin) and this different palaeotopographic condition could have been caused microclimatic condition in Greece (Popov et al. 2004; Fig. 11). Evia Island is located east to Spanokhorian, and the parameters for Evia for the late Burdigalian are calculated from Reigel et al. (1989). These parameters are the MAT of $17.0-18.4{ }^{\circ} \mathrm{C}$, the CMT and WMT of $6.2-12.5^{\circ} \mathrm{C}\left(9.35^{\circ} \mathrm{C}\right)$ and $26.5-32.0^{\circ} \mathrm{C}$, the MAP 1146-1322 mm, and the MART $19.9{ }^{\circ} \mathrm{C}$. The palaeotopography of the Evia locality differs from Spanokhorion and it should be lowland based on the MART values (Popov et al. 2004; Figs 11, 12, Table 3). Numerical climatic data for the Langhian of Kolivata western Greece) are calculated based on the palynofloras described by Benda et al. (1982). The results from Kolivata are the MAT 15.6-21.7 ${ }^{\circ} \mathrm{C}$, the CMT 5.0-15.6 ${ }^{\circ} \mathrm{C}\left(10.3{ }^{\circ} \mathrm{C}\right)$, the WMT $24.7-27.9^{\circ} \mathrm{C}$ $\left(26.3{ }^{\circ} \mathrm{C}\right)$, the MAP $823.0-1520.0 \mathrm{~mm}$ and the MART $16^{\circ} \mathrm{C}$. According to the CA results and palynological data, the palaeoaltitude has declined from the late Burdigalian (MART values of the Spanokhorion; $34.65^{\circ} \mathrm{C}$ or $24.7^{\circ} \mathrm{C}$ ) to Langhian (MART values of Kolivata; $19.9^{\circ} \mathrm{C}$ ) in the western part of the Greece (Fig. 11).

\section{Germany}

Mosbrugger et al. (2005) recorded the palaeoclimatic evolution during the Eocene-Pliocene interval based on the macro and microfloras from Germany and central Europe. The climatic curves of central Europe (Mosbrugger et al. 2005) are correlated with the climatic curves of oxygen and carbon isotopes (Zachos et al. 2008). For MAT and WMT, similar values are obtained from the floras of different $\mathrm{Ce}$ nozoic basins during this period. However, these authors observed the peak in the curve of CMT values $\left(9-13^{\circ} \mathrm{C}\right)$ for the Burdigalian-Langhian interval, and this increase of 


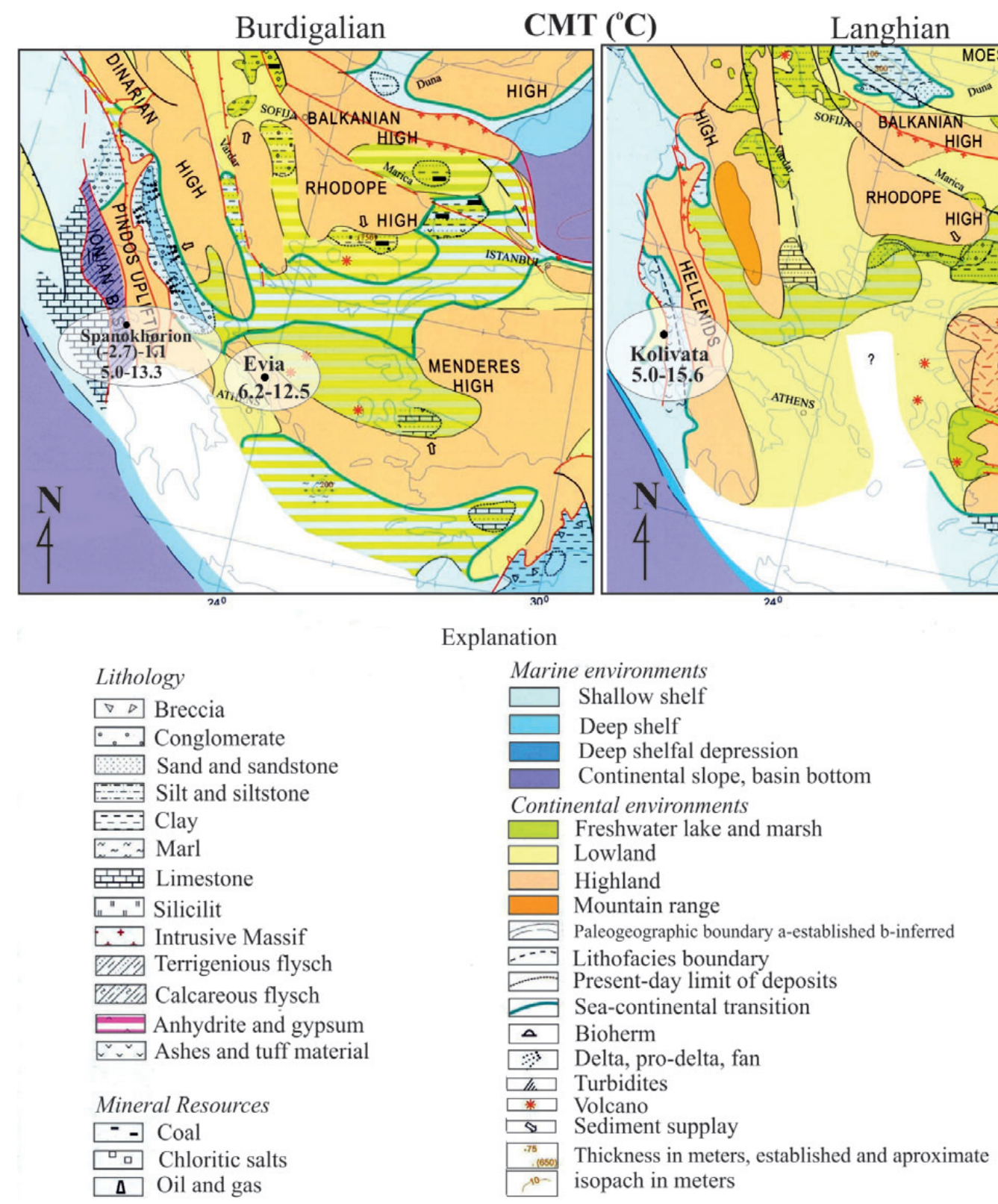

Figure 11. $\mathrm{CA}_{\text {palynoflora }}$ results (MAT, CMT, WMT, MAP and MART) of Greece for the Burdigalian-Langhian time interval and palaeogeography of Greece and western Turkey.

temperature is related to the warm climatic conditions (Mosbrugger et al. 2005). Besides, these authors emphasized that regional differences of climatic values are probably caused by palaeogeographic settings. For example, the Lower Rhine and the Weisselster-Lausitz basins are close to the Cenozoic North Sea, moderating the climate during the cold season. In the case of the Molasse Basin, orographic movements in the nearby area might be also influenced the palaeoclimate of this basin. The onset of the Miocene cooling seems to be between 13.0 and 14.0 my when considering all of the different records and climate variables analyzed. In the Molasse Basin, the CMT decreased more rapidly than in the other regions at the end of the middle Miocene and it dropped below $4{ }^{\circ} \mathrm{C}$ (Fig. 12).

\section{Bulgaria}

The palynoflora of the Langhian period in northeast Bulgaria was studied by Ivanov et al. $(2007,2011)$. During the Tarkhanian stage (Langhian), mixed mesophytic forests appear to have been widespread in the lowlands and mid-altitude uplands surrounding the deposition area in Bulgaria. Quercus and Ulmus are recorded abundantly in these 
forests, accompanied by Castanea, Carya, Pterocarya, Juglans, Ilex, Eucommia, Betula, Carpinus and Corylus etc. Elements of the thermophilous plants such as Platycarya, Engelhardia, Symplocos, Reevesia, Sapotaceae, Araliaceae and Arecaceae are also abundantly present in the pollen spectra (Ivanov 1995; Palamarev \& Ivanov 1998; Palamarev et al. 1999; Stuchlik et al. 1999; Ivanov et al. 2002, 2007; Palamarev \& Ivanov 2004). Additionally, Ivanov et al. $(2007,2011)$ obtained numerical climatic results using the $\mathrm{CA}$ analysis of the Langhian for the northeast Bulgaria: the MAT $13.6-17.2^{\circ} \mathrm{C}\left(20.4{ }^{\circ} \mathrm{C}\right)$, the CMT $2.4-7.0^{\circ} \mathrm{C}\left(7.5^{\circ} \mathrm{C}\right)$, the WMT $24.7-27.8^{\circ} \mathrm{C}\left(26.25^{\circ} \mathrm{C}\right)$, the MAP $823-1206 \mathrm{~mm}$ and the MART $18.75^{\circ} \mathrm{C}$ (Fig. 12). According to Meulenkamp \& Sissingh (2003) and Ivanov et al. (2007), a tectonic controlled reorganization in the latest Early to earliest Middle Miocene in the Eastern Paratethys resulted in the emergence of the Greater Caucasian archipelago and this tectonic uplift was flowed by a transgression in the territories west to the Black Sea. These authors hypothesized that tropical and subtropical water, which came by way of transgression from Black Sea affected the climate of the terrestrial areas in Bulgaria and thermophilous elements become abundant in the palynospectra of the Tarkhanian time. Additionally, the highland areas in northeast Bulgaria are known as existing since the Early Miocene and they were covered by the mixed mesophytic forest. Besides, the Balkan Peninsula apparently played a significant role in the origin, evolution, and migration of the Mediterranean vegetation during the Miocene, being situated between the Tethyan and Paratethyan realms (Palamarev 1989, Rögl 1998, Ivanov et al. 2007).

\section{Serbia}

Langhian floras in Serbia (Popovac, Slanci and Misaca floras) are recorded by Utescher et al. (2007). The Popovac palynoflora is represented by the deciduous plants (i.e. Acer, Rhamnus) and their presence indicates highland areas in Serbia during the Langhian-early Serravallian. Utescher et al. (2007) emphasize that the Slanci palynoflora is dominated by the species of Lauraceae family. Typical temperate deciduous taxa, such as Salix, Alnus, Рориlus and Acer, but also Engelhardia, Zelkova and conifers, reach minor percentages in the Slanci palynoflora. In the Misaca palynoflora, the arctotertiary elements (temperate elements; Mai 1981, 1991) Acer, Ulmus and Carpinus are well-represented. According to Utescher et al. (2007) these taxa migrated to Serbia across the higher altitudes of the ri- sing Carpathian mountain range. Additionally, these authors stated that deciduous and arctotertiary taxa form an important component of the mixed mesophytic vegetation of Central Europe during the Langhian-early Serravallian. Utescher et al. (2007) calculated palaeoclimatic data from Serbia by the CA. Resulting coexistence intervals of the Popovac flora are for the MAT 14.4-21.3 ${ }^{\circ} \mathrm{C}$, CMT $3.7-13.3^{\circ} \mathrm{C}\left(8.5^{\circ} \mathrm{C}\right)$, WMT $27.2-28.1^{\circ} \mathrm{C}\left(27.65^{\circ} \mathrm{C}\right)$ and MART $19.15^{\circ} \mathrm{C}$. The coexistence intervals of the Slanci flora are the MAT ranges from the $15.6-16.5^{\circ} \mathrm{C}$, the CMT 7-7 ${ }^{\circ} \mathrm{C}$, the WMT $25.6-27^{\circ} \mathrm{C}$, the MART $19^{\circ} \mathrm{C}$ and the MAP $823-1237 \mathrm{~mm}$. The values of the Misaca flora are 14.4 to $16.6{ }^{\circ} \mathrm{C}$ for the MAT, 5.6 to $11.7{ }^{\circ} \mathrm{C}\left(8.65{ }^{\circ} \mathrm{C}\right)$ for the CMT, 25.7 to $28.1{ }^{\circ} \mathrm{C}$ for the WMT, $18.25^{\circ} \mathrm{C}$ for the MART and 867 to $1018 \mathrm{~mm}$ for the MAP (Fig. 12). These authors suggested that these coexistence intervals of the Popovac, Misaca and Slanci floras are higher than that of the early Burdigalian palynoflora and these high values point to the Mid-Miocene climatic optimum (Zachos et al. 2001, Utescher et al. 2007).

\section{Ukraine}

The palaeovegetation types and palaeoclimatic interpretations for the Langhian were separately defined for the Ukrainian Carpathian region and Ukraine Plain based on the macroflora. The Langhian-early Serravallian in the Carpathian Basin is characterized by a transgressive cycle according to Venglinsky (1975) and Syabryaj et al. (2007). These authors emphasized that a seaway existed between the Central Paratethys and Tethys, and warm oceanic waters stimulated the presence of thermophilous ferns. Expanding broad-leaved forest includes Ulmus, Castanea and frequent Engelhardia in the Ukrainian Carpathian region. Langhian palaeovegetation of the elevated and slope areas in the Ukrainian Carpathian region, which is characterized by Picea and Ulmus, differs from the palaeovegetation of the inner zone of the Ukrainian Carpathians. The CA results of the Ukrainian Carpathian region display the MAT values between 15.6 and $18.4{ }^{\circ} \mathrm{C}$, the CMT between 6.6 to $12.5{ }^{\circ} \mathrm{C}\left(9.55{ }^{\circ} \mathrm{C}\right)$, the WMT values between 25.4 to $27.9^{\circ} \mathrm{C}$, the MART value of $17.1^{\circ} \mathrm{C}$ and the MAP between 1122 and $1213 \mathrm{~mm}$ (Syabryaj et al. 2007; Fig. 12). In the early Middle Miocene, the Ukrainian Plain was characterized by a regressive phase. The continental areas of this region were covered by pine forests (Keteleeria, Tsuga, Cedrus, Picea, Ginkgo and Podacarpus). The swamp forest

Figure 12. A - climatic records (MAT, CMT and WMT) for the Miocene of the Central and Eastern Paratethys (Serbia: Utescher et al. 2007a, modified; Ukraine, Syabryaj et al. 2007, modified, and Bulgaria, Ivanov et al. 2011, modified) and the eastern Mediterranean regions (Greece and Turkey: this study) compared to the continental climatic record of northern Germany (Utescher et al. 2009). B - climatic curve based on the average climatic values. - $\mathrm{C}$ - the marine oxygen isotope record (Zachos et al. 2001). Abbreviations: Ch - Chukourovo, Ru - Ruzhintsi, Ka - Koshava, Dr - Drenovets. 

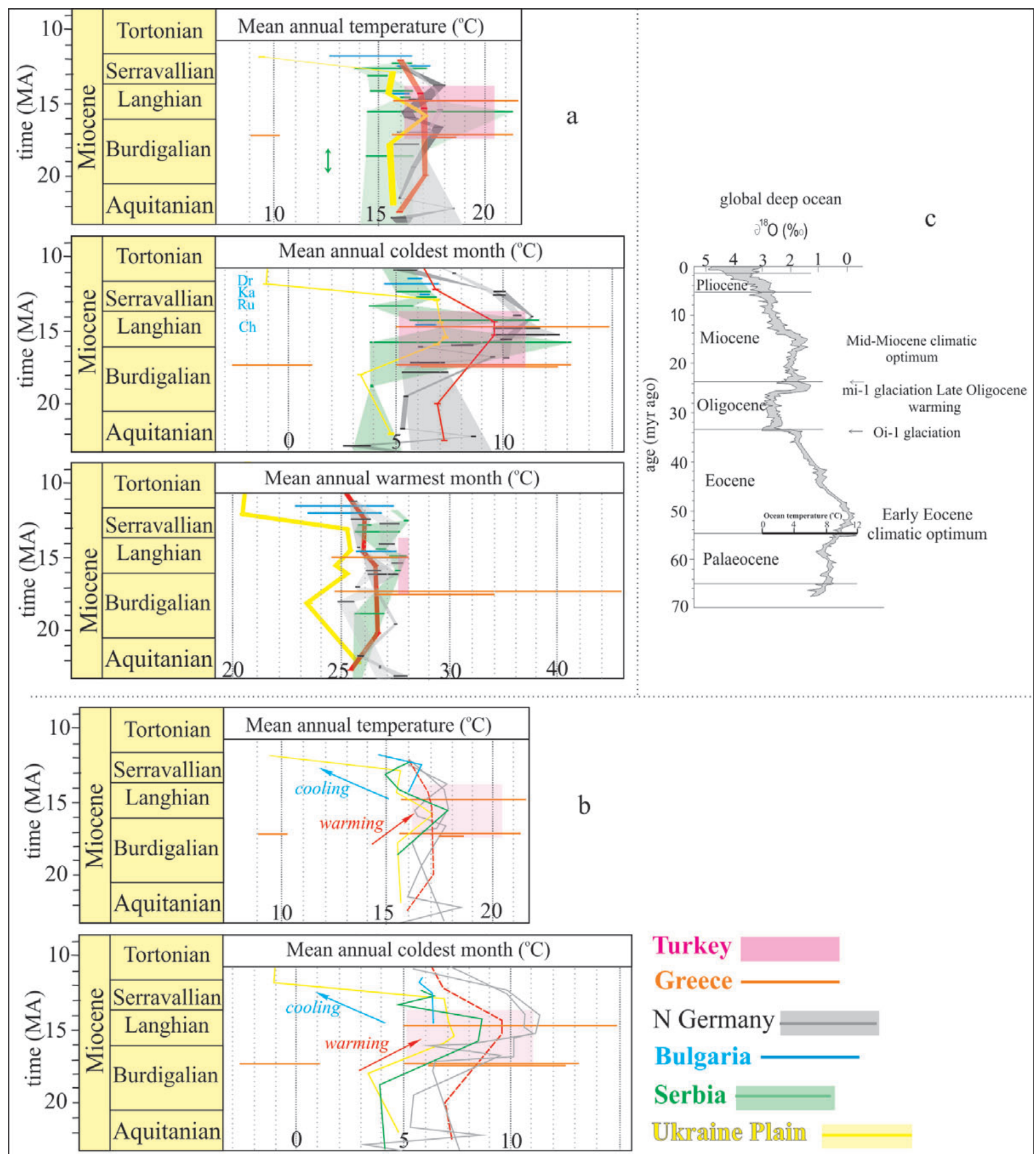

Turkey

Greece

N Germany

Bulgaria

Serbia

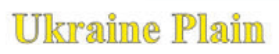

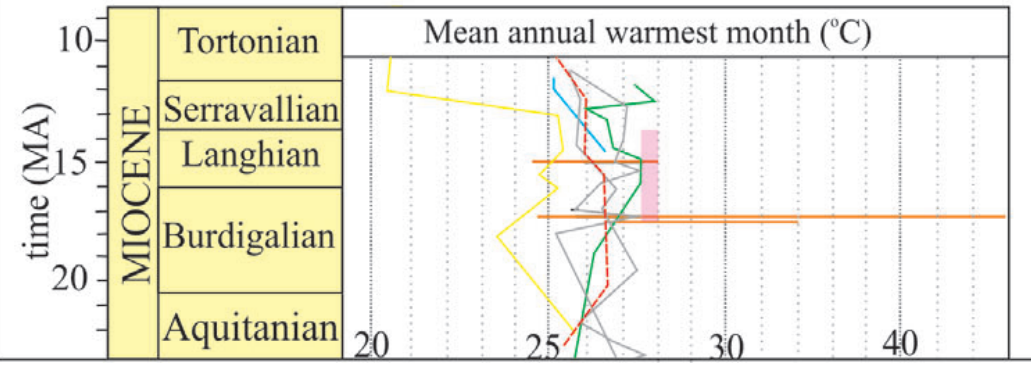

Ukrainian Carpathians 


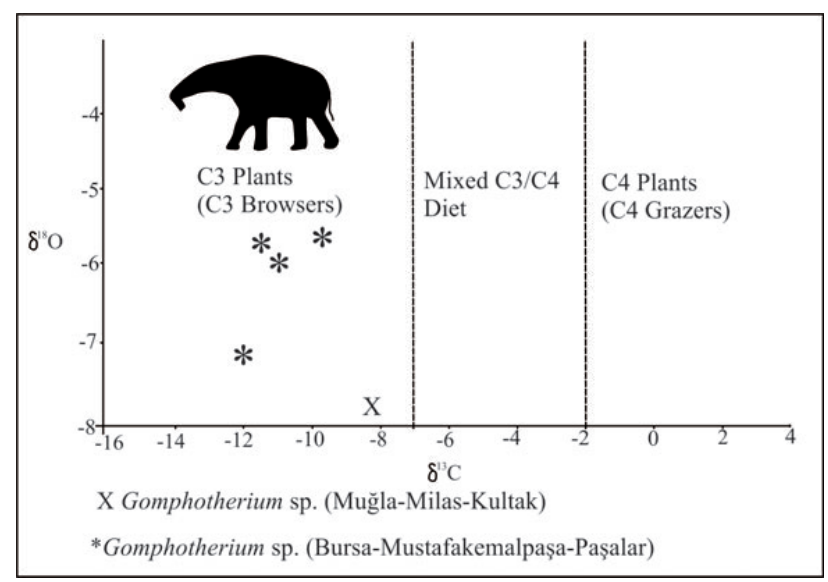

Figure 13. Stable carbon and oxygen isotope values of Kultak and Paşalar localities (Quade et al. 1995).

with Taxodium occurred in the most humid continental areas of the Ukrainian Plain. The broad-leaved forest was characterized by Quercus, Ulmus, Zelkova, Castaneae, $\mathrm{Li}$ quidambar, Fagus, Pterocarya, Juglans, Carpinus and Betula. In the undergrowth of this forest, Corylus, Erica, Lauraceae, Buxus, Ilex, Palmae and Theaceae occurred; this plant community points to the subtropical climatic conditions in the Ukrainian Plain. Salix and Alnus cloaked the river valleys and lakes. Furthermore, some herb species were recorded in samples from Ukrainian Plain. The resulting coexistence intervals of the Ukranian Plain are calculated by Syabryaj et al. (2007) as the MAT ranges from the 17-17.1 ${ }^{\circ} \mathrm{C}$, the CMT $6.6-7.1{ }^{\circ} \mathrm{C}\left(6.85{ }^{\circ} \mathrm{C}\right)$, the WMT 24.7-25.9 ${ }^{\circ} \mathrm{C}$, the MART $18.45{ }^{\circ} \mathrm{C}$ and the MAP 1146-1322 mm (Fig. 12).

The MAT, CMT and WMT values indicate some differences between the different regions of Europe due to their palaeogeographic position and the palaeotopography during the Burdigalian-Langhian period. However, climatic curves of these countries show some similarities. For instance, numerical climatic values decrease from the Early to Middle Miocene in all these regions. The starting of this decline generally begins in the Langhian. Climatic values from Turkey and Greece for the Burdigalian-Langhian periods are high as in Europe. While the CMT values resemble the values of European countries, the MAT and WMT values are higher than in these countries (Fig. 12). The effects of the Middle Miocene Climatic Optimum, which covers the Burdigalian-Langhian time interval, are observed as well in the palaeoclimatic records of Europe, Turkey and Greece (Fig. 12). The differences of the mean annual range of the temperature values (MART) were used as indicators for continental climatic condition and/or seasonality (see Bruch et al. 2004, Yao et al. 2011). Based on the high MART values from Turkey for the BurdigalianLanghian period, the presence of a high seasonality (warmer summers and colder winters) could be deduced. As a result, the high seasonality in Turkey could be related to influences of the continental climate (Table 2; Yao et al. 2011).

\section{Stable isotope analysis and precipitation records of Turkey and Europe}

The carbon isotopic composition of carbonate in biogenic apatites and in most soils is dependent upon the carbon isotopic composition of the local vegetation. C3 plants include nearly all trees, most shrubs and herbs, and grasses that favor cool growing seasons. Regions receiving dominantly winter rains, such as the modern Mediterranean, are vegetated largely by $\mathrm{C} 3$ plants. Modern $\mathrm{C} 3$ plants average $-27 \pm 5 \%$ of or $\delta^{13} \mathrm{C}$. The $\delta^{13} \mathrm{C}$ value of $\mathrm{C} 4$ plants averages about $-13 \pm 3 \%$. $\mathrm{C} 4$ plants include grasses that favor warm growing seasons, as well as a few desert shrubs and herbs. $\mathrm{C} 4$ grasses are common in tropical, subtropical and temperate climates dominated by warm summer rainfall (Quade et al. 1995). The $\delta^{13} \mathrm{C}$ value of fossil tooth enamel from Kultak and Hüssamlar is $-8.32 \%$ o (Table 4). This value indicates that herbivorous mammals from Kultak and Hüssamlar mainly consumed C3 plants as those of the Bursa-Pașalar mammal locality (Quade et al. 1995).

The oxygen isotopic composition of bone phosphate is largely defined by the $\delta^{18} \mathrm{O}$ value of environmental water, and metabolic processes which vary from species to species (Luz \& Kolodny 1995, Quade et al. 1995). Of the two, the $\delta^{18} \mathrm{O}$ value of environment water has been shown to be the most important, and this is controlled by the $\delta^{18} \mathrm{O}$ value of local precipitation and by the extent to which rainfall is later modified by evaporation. Leafs can be strongly enriched in $\delta^{18} \mathrm{O}$ due to evaporation from leaf surface, the more so in an unshaded setting like a clearing or a forest canopy (Quade et al. 1995). Sternberg et al. (1989) documented systematic enrichment in $\delta^{18} \mathrm{O}$ of foliage upward through a tropical forest. This isotopic stratification appears to be reflected in the $\delta^{18} \mathrm{O}$ value of mammals that consume such vegetation. The $\delta^{18} \mathrm{O}$ value is low in Gomphotherium sp. from Ören and Bursa-Pașalar (Table 4). This result could indicate that this large elephantoid was eating plants shielded from sunlight, as in a shaded forest setting (Fig. 13). Carbon and oxygen values of the Kultak, Hüssamlar and Pașalar localities are located in the range of $\mathrm{C} 3$ plants as shown in Fig. 13. This indicates similar ecological conditions during the Burdigalian-Langhian time. This isotopic result and high $\mathrm{MAP}_{\mathrm{DRY}}$ value of Kultak are in agreement with ecological interpretation from mammalian fossils. However, according to the isotopic results, the Kultak and Hüssamlar localities are more shaded than Bursa-Pașalar. Negative $\delta^{18} \mathrm{O}$ values could be indicative of less humidity in the Ören region (Table 3).

The MAP, $\mathrm{MAP}_{\mathrm{WET}}$ and $\mathrm{MAP}_{\mathrm{WARM}}$ values of Karacaağaç, Hüssamlar and Kultak localities in the SW Anatolia 
Table 3. $\mathrm{CA}_{\text {palynoflora }}$ results (MAT, CMT, WMT and MAP) of the Burdigalian-Langhian time interval in Greece.

\begin{tabular}{|c|c|c|c|c|c|c|c|}
\hline Location & Climate & References & $\operatorname{MAT}\left({ }^{\circ} \mathrm{C}\right)$ & $\mathrm{CMT}\left({ }^{\circ} \mathrm{C}\right)$ & WMT $\left({ }^{\circ} \mathrm{C}\right)$ & $\operatorname{MART}\left({ }^{\circ} \mathrm{C}\right)$ & MAP (mm) \\
\hline Grecee - Spanokhorion & $\begin{array}{l}\text { Warm } \\
\text { subtropical }\end{array}$ & $\begin{array}{l}\text { Benda (1971) } \\
\text { Benda et al. (1982) }\end{array}$ & $9.1-10.8$ or $15.6-21.3$ & $(-2.7)-1.1$ or $5.0-13.3$ & $24.7-43.0$ & 34.65 or 24.7 & $823-1520$ \\
\hline Grecee - Evia & $\begin{array}{l}\text { Warm } \\
\text { subtropical }\end{array}$ & Reigel et al. (1989) & $17.0-18.4$ & $6.2-12.5$ & $26.5-32.0$ & 19.9 & $1146-1322$ \\
\hline$*$ Grecee - Kolivata & $\begin{array}{l}\text { Warm } \\
\text { subtropical }\end{array}$ & $\begin{array}{l}\text { Benda (1971) } \\
\text { Benda et al. (1982) }\end{array}$ & $15.6-21.7$ & $5.0-15.6$ & $24.7-27.9$ & 16 & $823-1520$ \\
\hline
\end{tabular}

Table 4. Stable carbon and oxygen value of Kultak fossil site.

\begin{tabular}{lcccl}
\hline Sample & $\begin{array}{c}\mathrm{CO}_{3} \text {-content } \\
\left(\% \mathrm{CaCO}_{3}\right)\end{array}$ & $\begin{array}{c}\delta^{13} \mathrm{C} \\
(\% \circ \mathrm{VPDB})\end{array}$ & $\begin{array}{c}\delta^{18} \mathrm{O} \\
(\% \circ \mathrm{VPDB})\end{array}$ & \\
\hline Gomphotherium sp. & 12.4 & -8.32 & -7.75 & Milas-Hüssamlar and Kultak (MN4e-6) \\
Gomphotherium sp. & - & $(-10)$ and $(-12)$ & $(-5)$ and $(-8)$ & Bursa-Pașalar (MN6) \\
\hline
\end{tabular}

Table 5. $\mathrm{CA}_{\text {palynoflora }}$ results (MAP, MAP ${ }_{\mathrm{WET}}$, MAP $\mathrm{DRY}_{\mathrm{D}}$ and $\mathrm{MAP} \mathrm{PARM}_{\mathrm{W}}$ ) of the Burdigalian-Langhian time interval in Turkey and Greece (“*” symbolized the palynoflora of the Langhian time).

\begin{tabular}{|c|c|c|c|c|c|c|}
\hline \multicolumn{2}{|c|}{ Location } & \multirow{2}{*}{$\frac{\operatorname{MAP}(\mathrm{mm})}{1146-1322}$} & \multirow{2}{*}{$\frac{\operatorname{MAP}_{\mathrm{WET}}(\mathrm{mm})}{225-227}$} & \multirow{2}{*}{$\frac{\operatorname{MAP}_{\mathrm{DRY}}(\mathrm{mm})}{7-32}$} & \multirow{2}{*}{$\frac{\operatorname{MAP}_{\text {WARM }}(\mathrm{mm})}{79-125}$} & \multirow{2}{*}{$\frac{\operatorname{MART}\left({ }^{\circ} \mathrm{C}\right)}{17.95}$} \\
\hline$\underset{2}{2}$ & Ören-Karacaağaç & & & & & \\
\hline $\begin{array}{l}E \\
\infty \\
s\end{array}$ & Ören-Hüssamlar & $1146-1322$ & $225-227$ & $8-32$ & $79-125$ & 17.95 \\
\hline E & Ören-Kultak & $1122-1520$ & $204-227$ & $19-43$ & $79-125$ & 13.5 \\
\hline \multirow{11}{*}{ 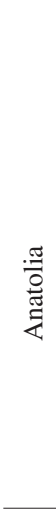 } & Ankara-Çayırhan (upper coal seam) & $735-1520$ & $134-180$ & $26-27.9$ & $55-125$ & 17.9 or 25.95 \\
\hline & Ankara-Çayırhan (lower coal seam) & $1146-1322$ & $225-245$ & $19-32$ & $79-154$ & 17.2 \\
\hline & Samsun-Havza & $1217-1322$ & $236-255$ & $19-32$ & $118-125$ & 17.45 \\
\hline & Çanakkale-Çan & $735-1520$ & $175-180$ & $8-43$ & $45-163$ & 14 \\
\hline & Çanakkale-Etili & $1146-1151$ & - & - & - & 20.8 \\
\hline & Balıkesir-Gönen & $437-1520$ & $175-180$ & $8-43$ & $45-61$ & 14 \\
\hline & Balıkesir-Bigadiç & $1217-1322$ & $109-180$ or $204-227$ & $16-43$ & $118-125$ & 17.45 \\
\hline & Manisa-Soma & $629-1520$ & $134-180$ & $8-43$ & $51-63$ & 17.9 \\
\hline & İzmir-Sabuncubeli & $1146-1322$ & - & - & - & 18.3 \\
\hline & Aydın- Kuloğulları & $1183-1520$ & $107-180$ or $205-245$ & $8-43$ & $85-163$ & 19.2 \\
\hline & Aydın-Bașçayır & $735-1574$ & $107-323$ & $5-43$ & $51-180$ & 17.6 \\
\hline \multirow{3}{*}{ 过 } & Spanokhorion & $823-1520$ & $204-227$ & $8-43$ & $79-125$ & 34.65 or 24.7 \\
\hline & Evia & $1146-1322$ & $225-227$ & $8-32$ & $79-125$ & 19.9 \\
\hline & *Kolivata & $823-1520$ & $107-180$ or $204-227$ & $8-43$ & $79-125$ & 16 \\
\hline
\end{tabular}

resemble each other. However, the $\mathrm{MAP}_{\mathrm{DRY}}$ values of these localities indicate differences. This value of Kultak is distinctly higher than the $\mathrm{MAP}_{\mathrm{DRY}}$ values for the two other localities. Thus Kultak has moist areas during the Burdigalian-Langhian time interval according to the high $\mathrm{MAP}_{\mathrm{DRY}}$ value, while the low $\mathrm{MAP}_{\mathrm{DRY}}$ values from Karacaağaç and Hüssamlar indicate the presence of drier areas. These discrepancies of precipitation between the different localities in the Ören region may have affected the faunal composition. For example, drier local conditions at Hüssamlar compare to Kultak are evidenced based on physical properties of Prosantorhinus douvillei and Brachypotherium brachypus.

Several MAP values are recorded in central, northwest and western Anatolia for the Burdigalian-Langhian time interval. The MAP values of certain localities are low (Table 5). This low precipitation values could be interpreted as the occasional existence of quite dry periods. The MAP and $\mathrm{MAP}_{\mathrm{WARM}}$ values of these localities do not show reliable differences. However, there are noticeable changes in the $\mathrm{MAP}_{\mathrm{DRY}}$ values and these values for the central Anatolia and Bigadiç locality in western Anatolia are higher than the $\mathrm{MAP}_{\mathrm{DRY}}$ values of other localities. This difference of the $\mathrm{MAP}_{\mathrm{DRY}}$ values could indicate more rainfall, seasonality and/or presence of different palaeotopographic conditions in central Anatolia during the Burdigalian-Langhian time interval. 


\section{Conclusion}

1. In this study, Kultak, Hüssamlar and Karacaağaç palynoflora are described. These floras are dominated by the thermophilous plants (Engelhardia, Sapotaceae, Cyrillaceae, Avicennia, Palmae etc.).

2. In the middle Burdigalian-Langhian time interval, palaeoclimatic condition at the Kultak locality is warmer than in the other localities of Turkey (Çayırhan, Havza, Çan, Etili, Gönen, Bigadiç, Emet, Kirka and Kestelek, Sabuncubeli, Soma, Tire, Kuloğulları, Başçayır, Hüssamlar and Karacaağaç) based on the CMT values. This warming could be related to the different depositional systems at the Kultak locality, which is represented by deltaic sedimentary environments. The lower MART value, the composition of its mammalian fauna and its palynoflora support this environmental evidence. Climatic variables of Karacaağaç and Hüssamlar are different from the variable of Kultak because of widespread terrestrial condition in the Hüssamlar and Karacağaç areas. Based on Kultak, Hüssamlar and Karacaağaç palynofloral evidences and physical properties of mammalian taxa, palaeotopography of the Hüssamlar and Karacaağaç localities should be higher and dryer than in the Kultak locality. Besides, although there is a presence of environmental discrepancy, temperature values are high and humid warm subtropical climatic condition is prevalent in Turkey.

3. The fossil assemblages from the two main localities (Kultak and Hüssamlar), described briefly here below, are formed of terrestrial vertebrates;

- Brachypotherium brachypus is the first rhinoceros record at Kultak, associated to the proboscideans, bovids and equids collected during the former field seasons; this species is still poorly documented in Anatolia.

- The small sized rhino Prosantorhinus cf. douvillei from Hüssamlar, encountered in Anatolia for the first time, is also the earliest record of the subtribe Teleoceratina in Turkey.

- The occurrence of Prosantorhinus and Gomphotherium at Hüssamlar is the further evidence for the forested environment in the Hüssamlar area in agreement with palynological results of this paper.

- Prosantorhinus douvillei known in several Middle Miocene (MN5) localities in Europe is interpreted as inhabiting the areas with hard soil and dry climatic conditions because of the slender morphology of its limb bones.

4. According to the palynological studies for the Burdigalian-Langhian periods, vegetational groups are represented in Greece and Turkey by a similar plant distribution (Pinus haploxylon type, Cyrillaceae, Engelhardia, Cupressaceae-Taxodioidea, Castanae, Sapotaceae and Quercus). Palaeoclimatic values from Turkey resemble that of Greece and several European countries. However, palaeogeography has a strong effect on the palaeoclimatic condition in Greece during the Burdigalian-Langhian time interval.

5. The temperature difference between different regions during the middle Burdigalian and Langhian periods could be explained by the palaeogeographic position of countries. Despite some differences in the climatic values and plant distribution, warm climatic conditions dominated, based on the palynofloras, in Turkey, Greece and elsewhere in Europe during this time interval. This warming is related to the Middle Miocene Climatic Optimum period.

6. The MAP, MAP ${ }_{\text {WET }}$ and MAP WARM $_{\text {values of the }}$ Karacaağaç, Hüssamlar and Kultak localities resemble each other. However the MAP $\mathrm{DRY}_{\mathrm{DR}}$ of Kultak is distinctly higher than the $\mathrm{MAP}_{\mathrm{DRY}}$ values of other Ören region localities. The high $\mathrm{MAP}_{\mathrm{DRY}}$ value could be indicative of the humid climatic condition at Kultak during the Burdigalian-Langhian time interval and also low $\mathrm{MAP}_{\mathrm{DRY}}$ values could be interpreted as indicative of drier areas at Karacaağaç and Hüssamlar. The $\mathrm{MAP}_{\text {WET }}$ and MAP $\mathrm{PARM}_{\text {}}$ values of these localities are not distinctly differentiated. Furthermore, the MAP $\mathrm{DRY}_{\mathrm{D}}$ values of central Anatolia (Ankara-Çayırhan and Samsun-Havza) and of Bigadiç in western Anatolia are higher than the $\mathrm{MAP}_{\mathrm{DRY}}$ values of other localities in Turkey. This could be interpreted as the more rainfall in central Anatolia during the Burdigalian-Langhian time interval.

7. Carbon and oxygen isotope values obtained from the tooth enamel of Gomphotherium sp. from the Kultak, Hüssamlar and Pașalar localities indicate that this elephantoid preferably consumed C3 plants. This isotopic result and high $\mathrm{MAP}_{\mathrm{DRY}}$ value from the Kultak locality are in agreement with ecological interpretation of mammalian fossils.

\section{Acknowledgements}

This study was financially supported by Dokuz Eylül University, Graduate School of Natural and Applied Sciences (AFS, high licenses project numbers: $04 \mathrm{~KB}$ FEN 031) and Scientific and Technical Research Council of Turkey (TUBITAK grant code 104Y297), DAAD and the Senckenberg Museum in Frankfurt. Authors thank to the Aegean University projects (TTM/001/2011, TTM/002/2011) and the TUBITAK-RFBR grant code 111Y192 for the mammalian fossil study. We would like to thank Volker Wilde, Angela Bruch, Ayhan Ilgar, șükrü Yurtsever, Bora Sonuvar and Serkan Özer for help through the course of this work. We are grateful to Șevket Șen and anonymous referees for their critical and constructive reviews that significantly improved the manuscript. Special thanks to Šárka Doležalová, who is executive editor of the Bulletin of Geosciences, for all suggestions, and Alexey Tesakov for English improvements. 


\section{References}

AKGÜN, F. 1993. Palynological age revision of the Neogene Soma coal basin. Bulletin of the Geological Society of Greece 28, $151-170$.

AKgÜN, F., AKay, E. \& ERdoĞAn, B. 2002. Terrestrial to shallow marine deposition in central Anatolia: a palynological approach. Turkish Journal of Earth Sciences 11, 1-7.

Akgün, F., Akkiraz, M. S., Mosbrugger, V., Bruch, A., Utescher, T., Wilde, V. \& Bozcu, M. 2008. Early-Middle Miocene palynostratigraphy and palaeoclimate of the Biga Peninsula, Northwest Turkey. Terra Nostra 2, IPC-XII/IOPC-VIII Bonn, Germany Abstract Volume, p. 9.

AKGÜN, F. \& AKyol, E. 1999. Palynostratigraphy of the coalbearing Neogene deposits in Büyük Menderes Graben, Western Anatolia. Geobios 32, 367-383.

DOI 10.1016/S0016-6995(99)80013-8

Akgün, F., Kaya, T., Forsten, A. \& Atalay, Z. 2000. Biostratigraphic data (Mammalia and palynology) from the Upper Miocene Incesu Formation at Duzyayla (Hafik-Sivas, central Anatolia). Turkish Journal of Earth Sciences 9, 57-67.

AKGÜn, F. \& Kayseri, M.S. 2004. Climatic evolution and vegetational changes during the Miocene period in central Anatolia (Turkey). NECLIME Annual Meeting, Island of Crete (Greece), p. 7.

AKgÜn, F., Kayseri, M.S. \& AKkiRaz, M.S. 2004. Paleoclimatic evolution and vegetational changes from the Oligocene to Miocene in Turkey. NECLIME Annual Meeting, Island of Crete (Greece), p. 7.

AKgÜN, F., Kayseri, M.S. \& AKkiRAZ, M.S. 2007. Paleoclimatic evolution and vegetational changes during the Late Oligocene-Miocene period in western and central Anatolia (Turkey). Palaeogeography, Palaeoclimatology, Palaeoecology 253, 56-106. DOI 10.1016/j.palaeo.2007.03.034

Andrews, P. \& Kelley, J. 2007. Middle Miocene dispersals of apes. Folia Primatologica 78, 328-343.

DOI 10.1159/000105148

Beaudouin, C. 2003. Effets du dernier cycle climatique sur la végétation de la basse vallée du Rhône et sur la sédimentation de la plate-forme du golfe du Lion d'après la palynologie. 403 pp. PhD thesis, Université Claude Bernard Lyon 1, France.

BENDA, L. 1971. Grundzüge einer pollenanalytischen Gliederung des türkischen Jungtertiärs (Känozoikum und Braunkohle der Türkei 4). Beihhefte zum Geologischen Jahrbuch 113, 1-46.

Benda, L., Meulenkamp, J.E. \& Schmidt, R.R. 1982. Biostratigraphic correlations in the eastern Mediterranean Neogene; 6 , Correlation between sporomorph, marine microfossil and mammal associations from some Miocene sections of the Ionian islands and Crete (Greece). Newsletters on Stratigraphy 11, 83-93.

Bruch, A.A., Utescher, T., Alcalde-Olivares, C., Dolakova, N., Ivanov, D. \& Mosbrugger, V. 2004. Middle and Late Miocene spatial temperature patterns and gradients in Europe: preliminary results based on palaeobotanical climate reconstructions. Courier Forschungsinstitut Senckenberg 249, 15-27.

Cambon, G., Suc, J.-P., Aloisi, J.-C., Giresse, P., Monaco, A., Touzani, A., Duzer, D. \& Ferrier, J. 1997. Modern pollen de- position in the Rhône delta area (lagoonal and marine sediments), France. Grana 36, 105-113.

DOI 10.1080/00173139709362596

Casanovas-Vilar, I., Alba, D.M., Garcés, M., Robles, J.M. \& MoYÀ-SolÀ, S. 2011. Updated chronology for the Miocene hominoid radiation in Western Eurasia. Proceedings of the National Academy of Sciences 108, 5554-5559.

DOI 10.1073/pnas.1018562108

Cerdeno, E. 1996. Prosantorhinus, the small teleoceratine rhinocerotid from the Miocene of western Europe. Geobios 29, 111-124. DOI 10.1016/S0016-6995(96)80077-5

Ediger, V.Ș. 1990. Tortonian-Messinian palynomorphs from the easternmost Mediterranean region around İskenderun, Turkey. Micropaleontology 42, 189-205. DOI $10.2307 / 1485870$

Fauquette, S., Suc, J.-P., Jiménez-Moreno, G., Micheels, A., Jost, A., Favre, E., Bachiri-Taoufie, N., Bertini, A., Clet-Pellerin, M., Diniz, F., Farjanel, G., Feddi, N. \& Zheng, Z. 2007. Latitudinal climatic gradients in the Western European and Mediterranean regions from the Mid-Miocene (c. $15 \mathrm{Ma}$ ) to the Mid-Pliocene (c. 3.5 Ma) as quantified from pollen data, 481-502. In Williams, M., Haywood, A.M., Gregory, F.J. \& Schmidt, D.N. (eds) Deep-Time Perspectives on Climate Change: Marrying the Signal from Computer Models and Biological Proxies. The Micropalaeontological Society, Special Publications. The Geological Society, London.

Fortelius, M. 1990. Rhinocerotidae from Pasalar, Middle Miocene of Anatolia (Turkey). Journal of Human Evolution 19, 489-508. DOI 10.1016/0047-2484(90)90061-F

GAZIRY, A.W. 1976. Jungtertiare Mastodonten aus Anatolien (Turkei). Geologisches Jahrbuch, Reihe B 22, 3-143.

Gemici, Y., AkgüN, F. \& YILmazer, Ç. 1992. Akçașehir (Tire-İzmir) Neojen havzası fosil makro ve mikrofloras1. Doğa, Türk Botanik Dergisi 16, 383-393.

Gemici, Y., Akyol, E., Akgün, F. \& Seçmen, Ö. 1991. Soma kömür havzası fosil makro ve mikroflorası [Fossil macro- and micro-flora of Soma coal basin]. General Directorate of Mineral Research and Exploration of Turkey (MTA) Bulletin 112, 161-178. [in Turkish with English abstract]

Gentry, A.W. 1990. Ruminant artiodactyls of Pasalar, Turkey. Journal of Human Evolution 19, 529-550. DOI 10.1016/0047-2484(90)90063-H

GERAADS, D. 2003. Ruminants, other than Giraffidae from the Middle Miocene hominoid locality of Candir (Turkey). Courier Forschungsinstitut Senckenberg 240, 181-199.

Geraads, D., Gulec, E. \& Saraç, G. 1995. Middle Miocene ruminants from Inönü, central Turkey. Neues Jahrbuch für Geologie und Palaeontologie, Monatshefte 8, 462-474.

GöHLICH, U.B. 1999. Order Proboscidea, 157-168. In RössNER, G. \& HeIssig, K. (eds) The Miocene land mammals of Europe. Verlag Dr. Friedrich Pfeil, München.

GÖRÜR, N., ȘENGÖR, A.M.C., SAKINÇ, M., TÜYSÜZ, O., AKKÖK, R., Yiğitbaș, E., Oktay, F.Y., Barka, A.A., SARica, N., EcevitoĞLu, B., DemirbaĞ, E. \& Akyol, A. 1994. Cross-cutting rift systems of the Gökova region, SW Anatolia: Implications for the formation of the Aegean Sea. Bulletin of the Technical University of Istanbul 47, 275-292. 
GÖRÜr, N., ȘENGÖR, A.M.C., SAKINÇ, M., TÜYSÜZ, O., AKKÖK, R., Yiğitbaș, E., Oktay, F.Y., Barka, A.A., Sarica, N., Ecevitoğlu, B., DemirbaĞ, E., Ersoy, Ș., Algan, O., GüNEYSU, C. \& AKYol, A. 1995. Rift formation in the Gökova region, soutwest Anatolia: implications for the opening of the Aegean Sea. Geological Magazine 132, 637-650. DOI $10.1017 / \mathrm{S} 0016756800018884$

GöRÜR, N. \& TÜYsüZ, O. 2001. Cretaceous to Miocene palaeogeographic evolution of Turkey: Implications for hydrocarbon potential. Journal of Petroleum Geology 24, 119-146. DOI 10.1111/j.1747-5457.2001.tb00664.x

GüNGÖR, H.Y. 1991. Ankara (Beypazarl) Kömürlerinin Palinolojisi ve Paleoekolojisi. 38 pp. Licence thesis, Dokuz Eylül University, İzmir.

GüRER, Ö.F. \& Yímaz, Y. 2002. Geology of the Ören and surrounding areas, SW Anatolia. Turkish Journal of Earth Sciences 11,1-13.

HAMmer, Ø., HaRPER, D.A.T. \& RYAN, P.D. 2001. PAST: paleontological statistics software package for education and data analysis. Palaeontologia Electronica 4, 9 pp.

Harzhauser, M. \& Piller, W.E. 2007. Benchmark data of a changing sea - palaeogeography, palaeobiogeography and events in the Central Paratethys during the Miocene. Palaeogeography, Palaeoclimatology, Palaeoecology 253, 8-31. DOI 10.1016/j.palaeo.2007.03.031

HeISSIG, K. 1999. Family Rhinocerotidae, 175-188. In RösSNER, G. \& HeIssig, K. (eds) The Miocene land mammals of Europe. Verlag Dr. Friedrich Pfeil, München.

HeIssig, K. \& FeJfar, O. 2007. The mammals from Untermiozaen of Tuchorice in Northwest Bohemia - 1. The fossils of rhinoceros (Mammalia, Rhinocerotidae). Sborník Národního muzea v Praze, $\breve{R} a d a ~ B-$ přirodní vědy 63, 19-66.

Heusser, L. 1988. Pollen distribution in marine sediments on the continental margin of Northern California. Marine Geology 80, 131-147. DOI 10.1016/0025-3227(88)90076-X

Ivanov, D.A. 1995. Palynological data about the presence of the family Symplocaceae in the Miocene of Northwestern Bulgaria. Geologica carpathica 46, 37-40.

Ivanov, D., Ashraf, A.R. \& Mosbrugger, V. 2007. Late Oligocene and Miocene climate and vegetation in the Eastern Paratethys area (northeast Bulgaria), based on pollen data. Palaeogeography, Palaeoclimatology, Palaeoecology 255, 342-360. DOI 10.1016/j.palaeo.2007.08.003

Ivanov, D., Ashraf, A.R., Mosbrugger, V. \& Palamarev, E. 2002. Palynological evidence for Miocene climate change in the Forecarpathian Basin (Central Paratethys, NW Bulgaria). Palaeogeography, Palaeoclimatology, Palaeoecology 178, 19-37. DOI 10.1016/S0031-0182(01)00365-0

Ivanov, D., Utescher, T., Ashraf, A.R., Mosbrugger, V., Bozukov, V., Djorgova, N. \& Slavomirova, E. 2012. Late Miocene palaeoclimate and ecosystem dynamics in Southwestern Bulgaria - A study based on pollen data from the Gotse Delchev Basin. Turkish Journal of Earth Sciences 21, 187-211.

Ivanov, D., Utescher, T., Mosbrugger, V., Syabryaj, S., Djordjevic-Milutinovic, D. \& Molchanoff, S. 2011. Miocene vegetation and climate dynamics in Eastern and Central
Paratethys (Southeastern Europe). Palaeogeography, Palaeoclimatology, Palaeoecology 304, 262-275.

DOI 10.1016/j.palaeo.2010.07.006

JACCARD, P. 1908. Nouvelles recherches sur la distribution florale. Bulletin de la Société vaudoise des sciences naturelles 44, 223-270.

Kern, A., Harzhauser, M., Mandic, O., Roetzel, R., Coric, S., Bruch, A.A. \& Zuschin, M. 2011. Millennial-scale vegetation dynamics in an estuary at the onset of the Miocene Climate Optimum. Palaeogeography, Palaeoclimatology, Palaeoecology 304, 247-261.

DOI 10.1016/j.palaeo.2010.07.014

KarayıĞit, A.İ., Akgün, F., Gayer, R.A. \& Temel, A. 1999. Quality, palynology, and palaeoenvironmental interpretation of the Ilgin lignite, Turkey. International Journal of Coal Geology 38, 219-236. DOI 10.1016/S0166-5162(98)00015-9

Kaya, T., TunA, V. \& GeraAds, D. 2001. A new late Orleanian/early Astaracian mammalian fauna from Kultak (MilasMugla), southwestern Turkey. Geobios 34, 673-680.

DOI 10.1016/S0016-6995(01)80028-0

KAYSERI, M.S. 2010. Oligo-Miocene Palynology, Palaeobotany, Vertebrate, Marine Faunas, Palaeoclimatology and Palaeovegetation of the Ören Basin (North of the Gökova Gulf), Western Anatolia. PhD thesis, Dokuz Eylül University, İzmir.

KAYSERI, M.S. \& AKGÜN, F. 2008. Late Burdigalian-Langhian time interval in Turkey -palaeoenvironment and palaeoclimatologic implications and correlation of Europe and Turkey. Terra Nostra 2008/2, IPC-XII/IOPC-VIII, p. 138.

KAYSERI, M.S. \& AKGÜN, F. 2010. The Late Burdigalian-Langhian time interval in Turkey and the palaeoenvironment and palaeoclimatic implications and correlation of Europe and Turkey: Late Burdigalian-Langhian palynofloras and palaeoclimatic properties of the Muğla-Milas (Kultak). Geological Bulletin of Turkey 53, 1-44.

Kayseri, M.S., AKGÜN, F., Kaya, T. \& Mayda, S. 2006. Palynological and faunal inventions of the Oligo-Miocene period in the Muğla-Kultak region, Western Anatolia (Turkey); preliminary results. $7^{\text {th }}$ European Palaeobotany and Palynology Conference (Prague), p. 63.

Kayseri, M.S., Akgün, F. \& ÖrçEn, S. 2007. Stratigraphy and microfaunal data of the Oligocene and Miocene ages in the Alakilise and Kultak regions (Gökova region). NECLIME Annual Meeting (Slovakia), p. 15.

Kovach, W.L. 1988. Multivariate methods of analyzing paleoecological data, 72-104. In DiMichele, W.A. \& Wing, S.L. (eds) Methods and Applications of Plant Paleoecology. The Paleontological Society, Special Publication 3.

Kovach, W.L. 1989. Comparisons of multivariate analytical techniques for use in pre-Quaternary plant paleoecology. Review of Palaeobotany and Palynology 60, 255-282. DOI 10.1016/0034-6667(89)90046-8

KoHLER, M. 1987. Boviden des turkischen Miozans (Kanozoikum und Braunkohlen der Turkei 28). Paleontologia i Evolucio 21, 133-246.

Mayda, S., Saraç, G. \& Kavușan, G. 2006. 'Gomphotherium angustidens (Cuvier)' (Proboscidea, Mammalia) from the 
Hanc1l1 Formation (Kalecik, Ankara): oldest Neogene Proboscidea record from Turkey. 55. Turkish Geology Symposium, Ankara, 254-255.

MAI, D.H. 1981. Entwicklung und klimatische Differenzierung der Laubwaldflora Mitteleuropas im Tertiär. Flora 171, 525-582.

MAI, D.H. 1991. Palaeofloristic changes in Europe and the confirmation of the Arcto-Tertiary-Palaeotropical geofloral concept. Review of Palaeobotany and Palynology 68, 29-36. DOI 10.1016/0034-6667(91)90055-8

Meulenkamp, J.E. \& Sissingh, W. 2003. Tertiary palaeogeography and tectonostratigraphic evolution of the Northern and Southern Peri-Tethys platforms and the intermediate domains of the African-Eurasian convergent plate boundary zone. $\mathrm{Pa}$ laeogeography, Paleoclimatology, Paleoecology 196, 209-228. DOI 10.1016/S0031-0182(03)00319-5

Mosbrugger, V. \& Utescher, T. 1997. The coexistence approach, a method for quantitative reconstructions of Tertiary terrestrial palaeoclimate data using plant fossils. Palaeogeography, Palaeoclimatology, Palaeoecology 134, 61-86. DOI 10.1016/S0031-0182(96)00154-X

Mosbrugger, V., Utescher, T. \& Dilcher, D.L. 2005. Cenozoic continental climatic evolution of Central Europe. Proceedings of the National Academy of Sciences 102(42), 14964-14969. DOI 10.1073/pnas.0505267102

NaKoman, E. 1978. Investigation of coal deposits Tinas, Bağyaka, Bayır, Eskihisar, Sekköy and Hüsamlar in SW Turkey. 140 pp. Tübitak project, İzmir. [in Turkish]

Quade, J., Cater, J.M.L., OJha, T.P. \& Harrison, T.M. 1995. Paleodietary reconstruction of Miocene faunas from Paşalar, Turkey using stable carbon and oxygen isotopes of fossil tooth enamel. Journal of Human Evolution 4, 373-384. DOI 10.1006/jhev.1995.1029

Querol, X., Alastuey, A., Plana, F., Lopez-Soler, A., Tuncali, E., TopraK, S., OcaKoĞLu, F. \& KoKer, A. 1999. Coal geology and coal quality of the Miocene Muğla Basin, southwestern Anatolia, Turkey. International Journal of Coal Gelology 41, 311-332. DOI 10.1016/S0166-5162(99)00025-7

Palamarev, E. 1989. Palaeobotanical evidences of the Tertiary history and origin of the Mediterranean sclerophyll dendroflora. Plant Systematic Evolution 162, 93-107. DOI 10.1007/BF00936912

Palamarev, E. \& Ivanov, D. 1998. Über einige Besonderheiten der tertiären Floren in Bulgarien und ihre Bedeutung für die Entwicklungsgeschichte der Pflanzenwelt in Europa. Acta Palaeobotanica 38, 147-165.

Palamarev, E. \& Ivanov, D. 2004. Badenian vegetation of Bulgaria: biodiversity, palaeoecology and palaeoclimate. Courier Forschungsinstitut Senckenberg 249, 63-69.

Palamarev, E., Ivanov, D. \& Bozukov, V. 1999. Paläoflorenkomplexe im Zentralbalkanischen Raum und ihre Entwicklungsgeschichte von der Wende Oligozän/Miozän bis ins Villafranchien. Flora Tertiaria Mediterranea 6(5), 1-95.

Popov, S.V., Rögl, F., Rozanov, A.Y., Steininger, F.F., Shcherba, I.G. \& Kovac, M.E. 2004. Lithological-palaeogeographic maps of Paratethys. 10 Maps Late Eocene to Pliocene. Courier Forschungsinstitut Senckenberg 250, $1-46$.
Reigel, A., Wehmeyer, D., Meinke, K., Schwarz, G., ApostoLiKAS, A. \& Velitzelos, E. 1989. Succession of depositional environments in the Neogene basin at Aliveri, Evia (Greece). Palaeogeography, Palaeoclimatology, Palaeoecology 70, 261-273. DOI 10.1016/0031-0182(89)90095-3

RöGL, V.F. 1998. Palaeogeographic considerations for Mediterranean and Paratethys seaways (Oligocene to Miocene). Annals of the Natural History Museum Vienna 99, 279-310.

Sickenberg, F., Becker-Platen, J.D., Benda, L., Berg, D., Engesser, B., Gaziry, W., Heissig, K., Hunermann, K.A., SonDaAr, P.Y., Schmidt-Kittler, N., Staesche, K., Staesche, U., Steffens, P. \& Tobien, H. 1975. Die Gliederung des höheren Jungtertiärs und Altquartärs in der Türkei nach Vertebraten und ihre Bedeutung fur die Internationale Neogen-Stratigraphie. Geologisches Jahrbuch, Reihe B 15, 1-167.

Sözbilir, H., Bozkurt, E., Winchester, J.A. \& Deniz, O. 2005. Ophiolites resting above the Gediz Detachment and their tectonic significance: field and geochemical evidence from Alașehir area, southwest Turkey. International Symposium on the Geodynamics of Eastern Mediterranean, Active Tectonics of the Aegean, p. 70.

SternBerg, L., MulKey, S.S. \& Wright, S.J. 1989. Ecological interpretation of leaf carbon isotope ratios: influence of respired carbon dioxide. Ecology 70, 1317-1324.

DOI $10.2307 / 1938191$

Stuchlik, L., Ivanov, D. \& Palamarev, E. 1999. Middle and Late Miocene floristic changes in the northern and southern parts of the Central Paratethys. Acta Palaeobotanica 2, 91-397.

SUC, J.-P. \& Drivaliari, A. 1991. Transport of bisaccate coniferous fossil pollen grains to coastal sediments: an example from the earliest Pliocene Orb Ria (Languedoc, Southern France). Review of Palaeobotany and Palynology 70, 247-253. DOI 10.1016/0034-6667(91)90006-O

Syabryaj, S., Utescher, T. \& Molchanov, S. 2007. Changes of climate and vegetation during the Miocene in the territory of Ukraine. Palaeogeography, Palaeoclimatology, Palaeoecology 253, 153-168. DOI 10.1016/j.palaeo.2007.03.038

Utescher, T., Bruch, A.A., Micheels, A., Mosbrugger, V. \& Popova, S. 2011. Cenozoic climate gradients in Eurasia palaeo-perspective on future climate change? Palaeogeography, Palaeoclimatology, Palaeoecology 304, 351-358. DOI 10.1016/j.palaeo.2010.09.031

Utescher, T., Erdei, B., Francois, L. \& Mosbrugger, V. 2007. Studies on diversity of plant functional types in the Miocene of Western Eurasia - spatial distribution patterns in the Langhian, Sarmatian and Tortonian, and their relation to palaeovegetation and palaeoclimate. Palaeogeography, Palaeoclimatology, Palaeoecology 253, 226-250.

DOI 10.1016/j.palaeo.2007.03.041

Whateley, M.K.G. \& TunCALi, E. 1995. Quality variations in the high-sulphur lignite of the Neogene Beypazar1 Basin, Central Anatolia, Turkey. International Journal of Coal Geology 27, 131-151. DOI 10.1016/0166-5162(94)00023-S

VENGLINSKY, I.V. 1975. Foraminifery biostratigrafiya miotsenovykh otlozheniy Zakarpatskovo progiba. 262 pp. Naukova dumka, Kiev. [in Russian] 
YAo, Y.F., Bruch, A.A., Mosbrugger, V. \& Li, C.S. 2011. Quantitative reconstruction of Miocene climate patterns and evolution in Southern China based on plant fossils. Paleogeography, Palaeoclimatology, Palaeoecology 304, 291-307. DOI 10.1016/j.palaeo.2010.04.012

YavuZ-Ișik, N. 2007. Pollen analysis of coal-bearing Miocene sedimentary rocks from the Seyitömer Basin (Kütahya), Western Anatolia. Geobios 40, 701-708.

DOI 10.1016/j.geobios.2006.11.006

Yilmaz, Y., Genç, Ș.C., Gürer, Ö.F., Bozcu, M., Yílmaz, K., Karacik, Z., Altunkaynak, Ș. \& Elmas, A. 2000. When did the Western Anatolia grabens begin to develop?, 353-384. In Bozkurt, E., Winchester, J.A. \& Piper, J.D.A. (eds) Tecton- ics and Magmatism in Turkey and the Surrounding Area. Geological Society of London, Special Publication 173.

Yilmaz, Y. \& Polat, A. 1998. Geology and evolution of the Thrace volcanism, Turkey. Acta Vulcanologica 10, 293-303.

Zachos, J.C., Dickens, G.R. \& Zeebe, R.E. 2008. An early Cenozoic perspective on greenhouse gas warming and carbon-cycle dynamics. Nature 451, 279-283.

DOI 10.1038/nature06588

Zachos, J., Pagani, M., Sloan, L., Thomas, E. \& Billups, K. 2001. Trends, rhythms, and aberrations in Global Climate 65 Ma to present. Science 292, 686-693.

DOI 10.1126/science.1059412 